\title{
Effects of salinity changes on zinc uptake and regulation by the decapod crustaceans Palaemon elegans and Palaemonetes varians
}

\author{
D. Nugegoda, P. S. Rainbow \\ Centre for Research in Aquatic Biology, School of Biological Sciences, Queen Mary College, University of London, \\ Mile End Road, London E1 4NS, England
}

\begin{abstract}
The decapod crustaceans Palaemon elegans Rathke and Palaemonetes varians (Leach) regulate their body concentrations of zinc to an approximately constant level (ca 76 to 82 and 90 to $99 \mu \mathrm{g}$ $\mathrm{Zng}^{-1}$ dry wt respectively) when exposed to a wide range of dissolved $\mathrm{Zn}$ concentrations, until a threshold dissolved concentration when regulation breaks down and net accumulation of body $\mathrm{Zn}$ begins. This threshold concentration decreases with decrease in salinity, from $100 \% \mathrm{SW}$ to $50 \% \mathrm{SW}$ in the case of $P$. elegans (ca 92 to $27 \mu \mathrm{g} \mathrm{Znl^{-1 }}$ respectively) and from $100 \%$ SW to $5 \% \mathrm{SW}$ in the case of $P$. varians (ca 191 to $19 \mu \mathrm{g} \mathrm{Zn} \mathrm{I}{ }^{-1}$ respectively), in correlation with increased rates of $\mathrm{Zn}$ uptake. $P$. elegans showed a further increased uptake rate in $25 \%$ SW $\left(1.054 \pm 0.385 \mu \mathrm{g} \mathrm{Zn} \mathrm{g} \mathrm{d}^{-1} \mathrm{~d}^{-1}\right.$ in $25 \%$ SW vs $0.735 \pm$

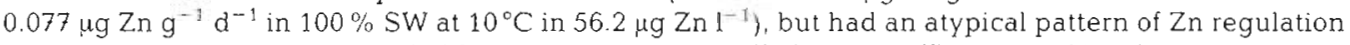
in raised $\mathrm{Zn}$ concentrations, probably as a result of atypically high $\mathrm{Zn}$ efflux caused by changes in water balance under osmotic stress. $P$. varians has a lower rate of $\mathrm{Zn}$ uptake than $P$. elegans under identical physico-chemical conditions ( $1.80 \pm 0.61$ vs $5.27 \pm 3.67 \mu \mathrm{g} \mathrm{Zn} \mathrm{g}{ }^{-1} \mathrm{~d}^{-1}$ in $100 \mu \mathrm{g} \mathrm{Zn} \mathrm{1^{-1 }}$ in $50 \% \mathrm{SW}$ ). Fifteen day acclimation of $P$. varians to either 50 or $25 \%$ SW did not significantly change the subsequent mean rate of $\mathrm{Zn}$ uptake from $100 \mu \mathrm{gn}^{-1}$ in $25 \% \mathrm{SW}$ The body $\mathrm{Zn}$ concentration of $P$. varians transferred to dilute media of 25 and $5 \%$ SW increased initially as a low salinity response but decreased again after 2 to $10 \mathrm{~d}$ to be regulated at ca $95 \mu \mathrm{g} \mathrm{Zn} \mathrm{g} \mathrm{g}^{-1}$ It is concluded that $\mathrm{Zn}$ uptake and regulation in decapods are affected both by extrinsic physico-chemical factors and by intrinsic adaptations of the species concerned.
\end{abstract}

\section{INTRODUCTION}

As is typical for decapod crustaceans (Rainbow 1988), the littoral prawn Palaemon elegans regulates the total body concentration of zinc to a constant level over a wide range of dissolved $\mathrm{Zn}$ concentrations (White \& Rainbow 1982, 1984a, b, Nugegoda \& Rainbow 1987). $\mathrm{Zn}$ is taken into the body at a rate which increases with the concentration of dissolved $\mathrm{Zn}$ to which the animal is exposed; over the regulated exposure range $\mathrm{Zn}$ uptake is matched by increasing $\mathrm{Zn}$ excretion, thereby maintaining a constant body $\mathrm{Zn}$ concentration (White \& Rainbow 1984a). Eventually Zn bioavailability exceeds a threshold and $\mathrm{Zn}$ excretion can no longer match $Z n$ uptake, causing regulation breakdown and net Zn accumulation (Rainbow 1988).

Physico-chemical variables affect the uptake of $\mathrm{Zn}$ by the prawn (White \& Rainbow 1984a, Nugegoda \& Rainbow 1988). For example, at a given dissolved $\mathrm{Zn}$ concentration, a rise in temperature causes an increase in the uptake rate by Palaemon elegans (White \& Rainbow 1984a). Increased Zn uptake in turn is correlated with a lowering of the threshold dissolved Zn concentration causing regulation breakdown in the prawn (Nugegoda \& Rainbow 1987). Similarly the presence of the chelating agent EDTA in solution decreases the rate of $\mathrm{Zn}$ uptake by $P$. elegans and thereby increases the dissolved $\mathrm{Zn}$ concentrations causing regulation breakdown (Nugegoda \& Rainbow 1988).

Changes in another physico-chemical variable, salinity, are known to affect the toxicity of heavy metals to marine and estuarine organisms (and also their uptake and accumulation), effects often differing between metals (Phillips 1980, McLusky et al. 1986). In the case of $\mathrm{Zn}$ and crustaceans, Jones (1975) showed that the toxicity of Zn to 6 species of marine and estuarine isopods increased as salinity decreased. McKenney \& 
Neff (1979) found that the viability of larval decapods Palaemonetes pugio in elevated $\mathrm{Zn}$ concentrations was reduced by both the individual effects of salinity and temperature and by interactions between the 2 factors outside optimal salinity-temperature conditions. Bryant et al. (1985) found that the toxicity of $\mathrm{Zn}$ to the amphipod Corophium volutator increased as salinity decreased over the range 35 to 5 ppt.

This paper reports on the effect of changes in salinity on $\mathrm{Zn}$ uptake and regulation by 2 prawns - Palaemon elegans and Palaemonetes varians. $P$. elegans lives in intertidal rockpools frequently encountering salinity changes from $100 \%$ to $50 \%$ seawater (Morris \& Taylor 1983). The related palaemonid $P$. varians is a salt marsh inhabitant of brackish waters of a lower salinity range and is never found in fully marine conditions (Smaldon 1979). The comparison is made to throw light on the relative importance of extrinsic physico-chemical factors (e.g. salinity changes) and intrinsic factors (e.g. adaptation to a specific osmotic range) on $\mathrm{Zn}$ uptake and regulation processes in decapod crustaceans. Parts of the study also examine the effects of salinity changes on $\mathrm{Zn}$ uptake in acclimated and non-acclimated prawns, and the effects of combined changes in salinity and temperature on $\mathrm{Zn}$ regulation in $P$. varians.

Results are presented to show that the breakdown in regulation of body $\mathrm{Zn}$ concentration occurs at lower dissolved $\mathrm{Zn}$ concentrations with decreased salinity in both prawns - over the range $100 \%$ to $50 \%$ SW for Palaemon elegans, and from $100 \%$ to $5 \% \mathrm{SW}$ for Palaemonetes varians. In both cases the decreases in dissolved $\mathrm{Zn}$ concentrations corresponding to thresholds of regulation breakdown are correlated with increases in $\mathrm{Zn}$ uptake rate. The rate of $\mathrm{Zn}$ uptake by $P$. elegans under given conditions is higher than that of $P$. varians and correspondingly $\mathrm{Zn}$ regulation breaks down at lower dissolved $\mathrm{Zn}$ concentrations in $P$. elegans. It will be concluded that $\mathrm{Zn}$ uptake and regulation in decapods are affected both by extrinsic physicochemical factors and by intrinsic adaptations of the species concerned.

\section{MATERIALS AND METHODS}

\section{Collection and analysis}

Palaemon elegans Rathke were collected from littoral rockpools near Millport, Isle of Cumbrae. Firth of Clyde, Scotland, and Palaemonetes varians (Leach) from a salt marsh at Tollesbury, Essex. England. The prawns were maintained in the laboratory at $10^{\circ} \mathrm{C}$ (12:12 h light: dark regime, continuous aeration). $P$. elegans at $100 \%$ SW (32 ppt salinity) and $P$. varians at $50 \%$ SW in artificial seawater (Tropic Marin New
[TMN], Tropicarium Buchschlag Dreieich, F. R. Germany). TMN was chosen as a reproducible medium,

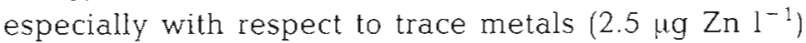
and potential chelating agents. Before and during experiments prawns were kept individually in compartmented Perspex boxes and fed every $2 \mathrm{~d}$ with

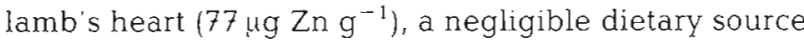
of $\mathrm{Zn}$, in separate feeding tanks (15 min) with clean TMN of appropriate salinity. Any prawns moulting in the $7 \mathrm{~d}$ before experiments were discarded.

For $\mathrm{Zn}$ analysis, prawns were individually frozen, then thawed, dried to constant weight at $60^{\circ} \mathrm{C}$ and digested in conc. $\mathrm{HNO}_{3}$ (Aristar grade, $\mathrm{BDH} \mathrm{Ltd}$ ) at $100^{\circ} \mathrm{C}$. Digests were made up to volume with doubledistilled water and analysed for total $\mathrm{Zn}$ by flame atomic absorption spectrophotometry (Varian AA 375 spectrophotometer with background correction) and/or analysed for Zn-65 activity (as a measure of accumulated labelled Zn concentration) in a Nuclear Chicago gamma scintillation counter against standards of the same sample geometry. When live prawns were monitored for Zn-65 activity, the method of White \& Rainbow (1984a) was used, all live counts being corrected against counts of the final acid digest of each prawn. No attempts were made to sex the prawns since White \& Rainbow (1984b) showed that the sex of Palaemon elegans has no effect on rates of $\mathrm{Zn}$ uptake or loss.

Raw data of body Zn concentrations were normalized by $\log$ transformation before use of a priori and a posteriori analysis of variance (Sokal \& Rohlf 1981). Regression lines were fitted by least squares.

\section{Experimental details}

Prawns were subjected to a stepwise decrease or increase in salinity over 1 to $3 \mathrm{~d}$ and acclimated for 3 to $5 \mathrm{~d}$ at the appropriate salinity (without added $\mathrm{Zn}$ ) before the start of any experiment.

Experiment 1: Effect of salinity on $\mathrm{Zn}$ regulation. Series of 7 tanks with $\mathrm{Zn}$ concentrations of 2.5 (Control), 31.6, 56.2, 100, 178, 316 and $562 \mu \mathrm{g} \mathrm{l}^{-1}$ were maintained for $21 \mathrm{~d}$ at $10^{\circ} \mathrm{C}$, each tank with 12 prawns individually held in a compartmented Perspex box, in TMN (a) as $100,75,50$ or $25 \%$ SW for palaemon elegans or (b) as $100,75,50,25$ or $5 \%$ SW for Palaemonetes varians. Samples of prawns acclimated for $3 \mathrm{~d}$ to each salinity (without added $\mathrm{Zn}$ ) were taken as Initials. Any dead prawns and moults were removed daily. After $21 \mathrm{~d}$, surviving prawns were rinsed briefly in clean TMN of the experimental salinity and frozen for $\mathrm{Zn}$ analysis.

Experiment 2: Palaemon elegans. Effects of salinity

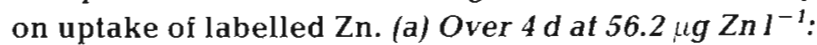
Experimental tanks were set up with $10 \mathrm{l}$ of TMN of 100 , 
75,50 or $25 \%$ SW, each containing a concentration of $56.2 \mu \mathrm{gl}^{-1}$ total $\mathrm{Zn}$ labelled with $4 \mu \mathrm{Ci}^{-1} \mathrm{Zn}-65$. In each tank, 12 prawns were held individually for $4 \mathrm{~d}$ at $10^{\circ} \mathrm{C}$. The uptake of labelled $\mathrm{Zn}$ in individual prawns was monitored by gamma counting of live specimens after 8 , $23,46,54,72$ and $96 \mathrm{~h}$, before prawns were frozen individually for analysis of total $\mathrm{Zn}$ and $\mathrm{Zn}-65$ activity in digests. Prawns were fed the day before the start of the experiment and after 31 and $54 \mathrm{~h}$. At the start of each experiment, 12 prawns acclimated to each salinity for $3 \mathrm{~d}$ (Initials) were taken. Control tanks of 100, 75, 50 and $25 \%$ SW with 12 individually held prawns were also maintained for $4 \mathrm{~d}$ under the same conditions of salinity and temperature and fed similarly.

(b) Over $21 \mathrm{~d}$ at $100 \mu \mathrm{g} \mathrm{Zn}^{-1}$ : Experimental tanks were set up with $15 \mathrm{l}$ of TMN of 100 or $50 \%$ SW, each with $100 \mu \mathrm{g} \mathrm{l}^{-1}$ total $\mathrm{Zn}$ labelled with $20 \mu \mathrm{Ci}{ }^{-1} \mathrm{Zn}-65$. In each tank, 20 prawns were held individually for $21 \mathrm{~d}$ at $10^{\circ} \mathrm{C}$, being fed every other day. Uptake of labelled $\mathrm{Zn}$ in individual live prawns was monitored after 6,12 , $24,31,48$ and $72 \mathrm{~h}$ and $4,5,8,11,14,16,18$ and $21 \mathrm{~d}$, before prawns were frozen individually for analysis for total $\mathrm{Zn}$ and $\mathrm{Zn}-65$ in digests. Control tanks (without added $\mathrm{Zn}$ ) with 15 individually held prawns fed similarly were also maintained in TMN of 100 and $50 \%$ SW for $21 \mathrm{~d}$ under the same conditions. The medium in each tank was replaced on Days 4, 9 and 15 with TMN of the same salinity and labelled $\mathrm{Zn}$ concentration. Water samples of $5 \mathrm{ml}$ from each experimental tank were taken periodically and counted to check for $\mathrm{Zn}$ loss from solution.

Experiment 3: Palaemonetes varians. Uptake of labelled $\mathrm{Zn}$ at $10^{\circ} \mathrm{C}$ in $50 \%$ and $25 \%$ SW. (a) After $15 \mathrm{~d}$ acclimation to $\mathbf{5 0} \% \mathbf{S W}$ : Two experimental tanks of $50 \%$ and $25 \%$ SW were prepared each with $100 \mathrm{\mu g} \mathrm{l}^{-1}$ total $\mathrm{Zn}$ and $4 \mu \mathrm{Ci} l^{-1} \mathrm{Zn}-65$. Fifteen individually held $P$. varians acclimated for $15 \mathrm{~d}$ in $50 \%$ SW were placed in each tank and held for $71 \mathrm{~h}$ at $10^{\circ} \mathrm{C}$, before being frozen for individual $\mathrm{Zn}$ analysis. Accumulation of labelled $\mathrm{Zn}$ in individual prawns was monitored by counting live specimens after $8,23,31,46,53$ and $71 \mathrm{~h}$. Prawns were fed before the start of the experiment and after $21 \mathrm{~h}$. The concentrations of dissolved labelled $\mathrm{Zn}$ in the media were periodically monitored.

(b) After $15 d$ acclimation to appropriate salinity $(50 \%$ or $25 \%$ SW): Expt 3 a was repeated with Palaemonetes varians acclimated for $15 \mathrm{~d}$ to the same salinity $(25 \%$ or $50 \% \mathrm{SW})$ to which the prawns would be exposed to $100 \mu \mathrm{g} \mathrm{Zn} \mathrm{l^{-1 }}$ for $71 \mathrm{~h}$.

Experiment 4: Palaemonetes varians. Effect of acclimation to low salinities on total body $\mathrm{Zn}$ concentration. $P$. varians collected from Toliesbury were transported back to the laboratory in water of ca $16 \mathrm{ppt}$ salinity, taken from the field site, and held overnight at $10^{\circ} \mathrm{C}$. Sixty prawns were placed in each of 3 tanks of
50, 25 and $10 \%$ SW respectively. Prawns were fed every other day in feeding tanks of the appropriate salinity for $15 \mathrm{~min}$. Six prawns from each salinity regime were frozen after $1,2,3,4,7,10,15$ and $21 \mathrm{~d}$ for analysis of zinc.

Experiment 5: Regulation of $\mathrm{Zn}$ by Palaemonetes varians in $50 \% \mathrm{SW}$ at $15^{\circ} \mathrm{C}$. Seven tanks were prepared with $\mathrm{Zn}$ concentrations of 2.5 (Control), 31.6, $56.2,100,178,316$ and $562 \mu \mathrm{gn} \mathrm{Zn}^{-1}$ in $50 \% \mathrm{SW}$ Twelve individually held $P$. varians were placed in each tank and maintained for $21 \mathrm{~d}$ at $15^{\circ} \mathrm{C} \pm 0.5 \mathrm{C}^{\circ}$ being fed every other day in feeding tanks with clean $50 \% \mathrm{SW}$ at $15^{\circ} \mathrm{C}$ for $15 \mathrm{~min}$. Dead prawns and moults were removed daily. After $21 \mathrm{~d}$, surviving prawns were individually frozen for $\mathrm{Zn}$ analysis.

\section{RESULTS}

\section{Experiment 1: Effect of salinity on Zn regulation}

Mean zinc concentrations initially in prawns acclimated to the appropriate salinity for $3 d$ (Initials), and mean $\mathrm{Zn}$ concentrations in control prawns held at the experimental salinity for $21 \mathrm{~d}$ (Controls) are shown in Table 1. In the case of Palaemon elegans, analysis of

Table 1. Palaemon elegans and Palaemonetes varians. Mean $\mathrm{Zn}$ concentrations ( $\mu \mathrm{g} \mathrm{g}^{-1} \pm 1 \mathrm{SD}$ ) of initial and control prawns from each experimental salinity at $10^{\circ} \mathrm{C}$, and in a sample (field) of $P$. varians immediately after field collection. ( $P$. elegans were not exposed to $5 \% \mathrm{SW}$ ). $n$ : number of samples

\begin{tabular}{|c|c|c|}
\hline \multirow{2}{*}{$\begin{array}{l}\text { Salinity } \\
(\% \text { SW) }\end{array}$} & \multicolumn{2}{|c|}{ Mean Zn concentration } \\
\hline & $\begin{array}{l}\text { Initials } \\
(n)\end{array}$ & $\begin{array}{c}\text { Controls } \\
(n)\end{array}$ \\
\hline \multicolumn{3}{|l|}{ Palaemon elegans } \\
\hline 100 & $\begin{array}{c}77.5 \pm 9.3 \\
(12)\end{array}$ & $\begin{array}{c}81.6 \pm 3.3 \\
(11)\end{array}$ \\
\hline 75 & $\begin{array}{c}79.2 \pm 10.6 \\
(12)\end{array}$ & $\begin{array}{c}80.2 \pm 7.9 \\
\text { (11) }\end{array}$ \\
\hline 50 & $\begin{array}{c}75.7 \pm 7.4 \\
(12)\end{array}$ & $\begin{array}{c}76.1 \pm 4.8 \\
(12)\end{array}$ \\
\hline 25 & $\begin{array}{c}77.8 \pm 5.9 \\
(12)\end{array}$ & $\begin{array}{c}76.9 \pm 8.1 \\
(7)\end{array}$ \\
\hline \multicolumn{3}{|c|}{ Palaemonetes varians } \\
\hline 100 & $\begin{array}{c}93.8 \pm 7.9 \\
(12)\end{array}$ & $\begin{array}{c}96.6 \pm 7.4 \\
(5)\end{array}$ \\
\hline 75 & $\begin{array}{c}94.8 \pm 6.1 \\
(12)\end{array}$ & $\begin{array}{c}90.2 \pm 9.6 \\
(12)\end{array}$ \\
\hline 50 & $\begin{array}{c}89.6 \pm 8.7 \\
(12)\end{array}$ & $\begin{array}{c}91.9 \pm 7.6 \\
(8)\end{array}$ \\
\hline 25 & $\begin{array}{c}104.9 \pm 4.7 \\
(12)\end{array}$ & $\begin{array}{c}94.3 \pm 10.2 \\
(12)\end{array}$ \\
\hline 5 & $\begin{array}{c}134.0 \pm 8.5 \\
\text { (12) }\end{array}$ & $\begin{array}{c}98.8 \pm 4.3 \\
(6)\end{array}$ \\
\hline $\begin{array}{l}\text { Field } \\
\text { (ca } 50 \% \text { SW) }\end{array}$ & $\begin{array}{c}98.8 \pm 5.8 \\
(12)\end{array}$ & \\
\hline
\end{tabular}


variance showed that in no case was there a significant difference $(p>0.05)$ between mean $\mathrm{Zn}$ concentrations of Initial and Control prawns at any salinity, and mean Zn concentrations did not differ significantly within the 4 sets of Initial prawns or within the 4 sets of Control prawns. Therefore exposure for $21 \mathrm{~d}$ to decreased salinities had no effect on the $\mathrm{Zn}$ concentration of Palaemon elegans.

For Palaemonetes varians (Table 1 ) in 100, 75 and $50 \% \mathrm{SW}$ mean $\mathrm{Zn}$ concentrations of Initials were not significantly different from those of Controls. However in $25 \%$ and $5 \% \mathrm{SW}$, mean $\mathrm{Zn}$ concentrations in Initials were significantly higher than in Controls. Initials in $25 \%$ and $5 \%$ SW also had significantly higher mean body $\mathrm{Zn}$ concentrations than all other Initials. This indicates an increase in body concentration within $3 \mathrm{~d}$ of transfer from $50 \% \mathrm{SW}$ as a response to low salinity in this species. After a further $21 \mathrm{~d}$ exposure to TMN at the 5 different salinities however, analysis of variance showed that the mean $\mathrm{Zn}$ concentrations of Control prawns in all salinities were not significantly different from each other. Therefore the elevation in body concentrations in the reduced salinities was no longer evident after $24 \mathrm{~d}$, and is a short-term phenomenon.

Body $\mathrm{Zn}$ concentrations of Palaemon elegans and Palaemonetes varians exposed to the range of dissolved $\mathrm{Zn}$ concentrations in $100,75,50,25$ and $5 \% \mathrm{SW}$ $\left(P\right.$. varians only) at $10^{\circ} \mathrm{C}$ for $21 \mathrm{~d}$ are shown in Figs. 1 and 2. Prawns moulting before Day 19 of the experiments had $\mathrm{Zn}$ concentrations not significantly different from those of non-moulters and have been included in all analyses. Prawns moulting on Days 19 to 21 inclusive had raised body $\mathrm{Zn}$ concentrations in comparison with non-moulters and have been excluded.

The results are interpreted as described by Nugegoda \& Rainbow (1987). Prawns are able to regulate total body $\mathrm{Zn}$ concentrations until a threshold exposure concentration is reached, when regulation breaks down and net accumulation of body $\mathrm{Zn}$ begins. After Nugegoda \& Rainbow (1987), a regulated range for body $\mathrm{Zn}$ concentrations of the prawns at each experimental salinity is defined as the mean $\mathrm{Zn}$ concentration \pm 1.96 standard deviations of Control prawns (log-transformed data) held for $21 \mathrm{~d}$ at the respective salinity (see Figs. 1 and 2). Prawns with total body concentrations greater than the defined upper regulation limit for each experiment were identified as non-regulators, showing further net accumulation of $\mathrm{Zn}$. Table 2 shows the number of surviving non-regulators (excluding moulters on Days 19 to 21) as a fraction of total survivors at the end of $21 \mathrm{~d}$ in each exposure concentration at each experimental salinity.

For Palaemon elegans, an a posteriori comparison showed that in $100 \%$ SW (Fig. 1a), there was no significant difference in mean prawn $\mathrm{Zn}$ concentrations up to the $178 \mu \mathrm{g} \mathrm{Zn} \mathrm{l}^{-1}$ exposure, and these were significantly lower than the mean $\mathrm{Zn}$ concentrations in prawns exposed to higher concentrations. In $75 \% \mathrm{SW}$ (Fig. 1b), there was no significant difference in mean

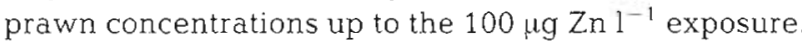
In $50 \% \mathrm{SW}$ (Fig. 1C) there was no significant difference between the mean $\mathrm{Zn}$ concentration of Control prawns

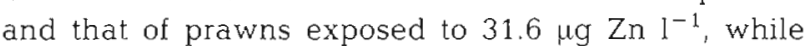
mean concentrations of prawns in all higher exposures were significantly raised. However in $25 \% \mathrm{SW}$ (Fig. 1d), although the mean $\mathrm{Zn}$ concentration of prawns in the $178 \mu \mathrm{g} \mathrm{Zn} \mathrm{I} \mathrm{I}^{-1}$ exposure was significantly higher than in other exposures, there was little identifiable breakdown in $\mathrm{Zn}$ regulation at higher external concentrations.

Thus breakdown in $\mathrm{Zn}$ regulation in Palaemon elegans occurs at lower external concentrations with decrease in salinity down to $50 \% \mathrm{SW}$, and a corresponding increase in the percentage of non-regulators was identified at higher exposure concentrations (Table 2). Significant regressions could be plotted for total body $\mathrm{Zn}$ concentrations versus $\mathrm{Zn}$ exposure concentrations after regulation breakdown at salinities of 100,75 and $50 \%$ SW (Figs. 1a to c). Estimates of the exposure concentration corresponding to the point of regulation breakdown under the specific experimental conditions used are provided by the intersections of these regression lines with regulated prawn $\mathrm{Zn}$ concentrations, the starting concentrations for further net $\mathrm{Zn}$ accumulation. These regulated prawns concentrations (indicated on the figures) have been obtained by back transformation of log-transformed data and therefore differ in detall from the arithmetic means of control prawns as quoted in Table 1 which do not differ significantly with salinity regime (Table 1). For $P$. elegans the points of regulation breakdown are ca 92, 55 and $27 \mathrm{\mu g} \mathrm{Zn} \mathrm{I}^{-1}$ in 100,75 and $50 \% \mathrm{SW}$ respectively. $\mathrm{Zn}$ accumulation patterns are summarised comparatively in Fig. 3. The pattern of $Z n$ accumulation by $P$. elegans at $25 \% \mathrm{SW}$ is clearly different from those at higher salinities with no clear pattern of $\mathrm{Zn}$ regulation breakdown in surviving prawns (Figs. $1 \mathrm{~d}$ and 3 ).

In the case of Palaemonetes varians (Figs. 2 and 4), similar treatment of the data showed that there was little difference between the thresholds of $\mathrm{Zn}$ regulation breakdown in 100,75 and $50 \% \mathrm{SW}$ at $10^{\circ} \mathrm{C}$, viz. 191, 183 and $146 \mu \mathrm{g} \mathrm{Zn} \mathrm{l}^{-1}$ respectively. In these 3

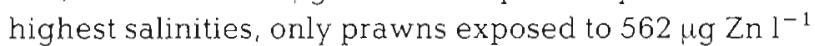
for $21 \mathrm{~d}$ had mean $\mathrm{Zn}$ concentrations significantly higher than that of the Controls. However, in $25 \% \mathrm{SW}$,

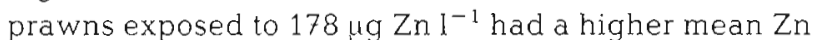
concentration $(p<0.05)$ than that of Controls and $7 / 12$ prawns were identified as non-regulators of total body Zn (Table 2). In $5 \%$ SW, $86 \%$ of prawns surviving $21 \mathrm{~d}$ exposure to $56.2 \mu \mathrm{g} \mathrm{Zn} \mathrm{l^{-1 }}$ were non-regulators. Few 

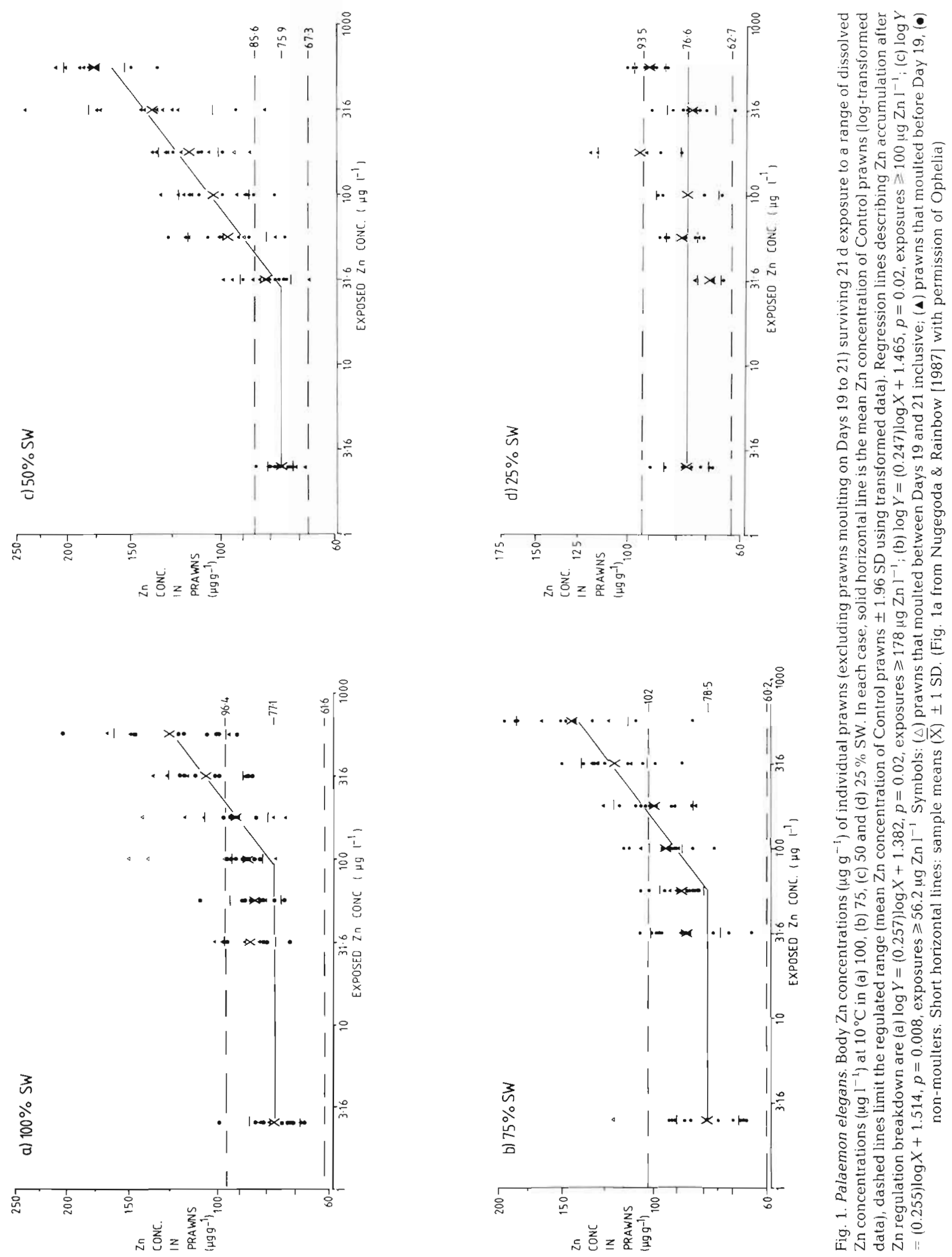

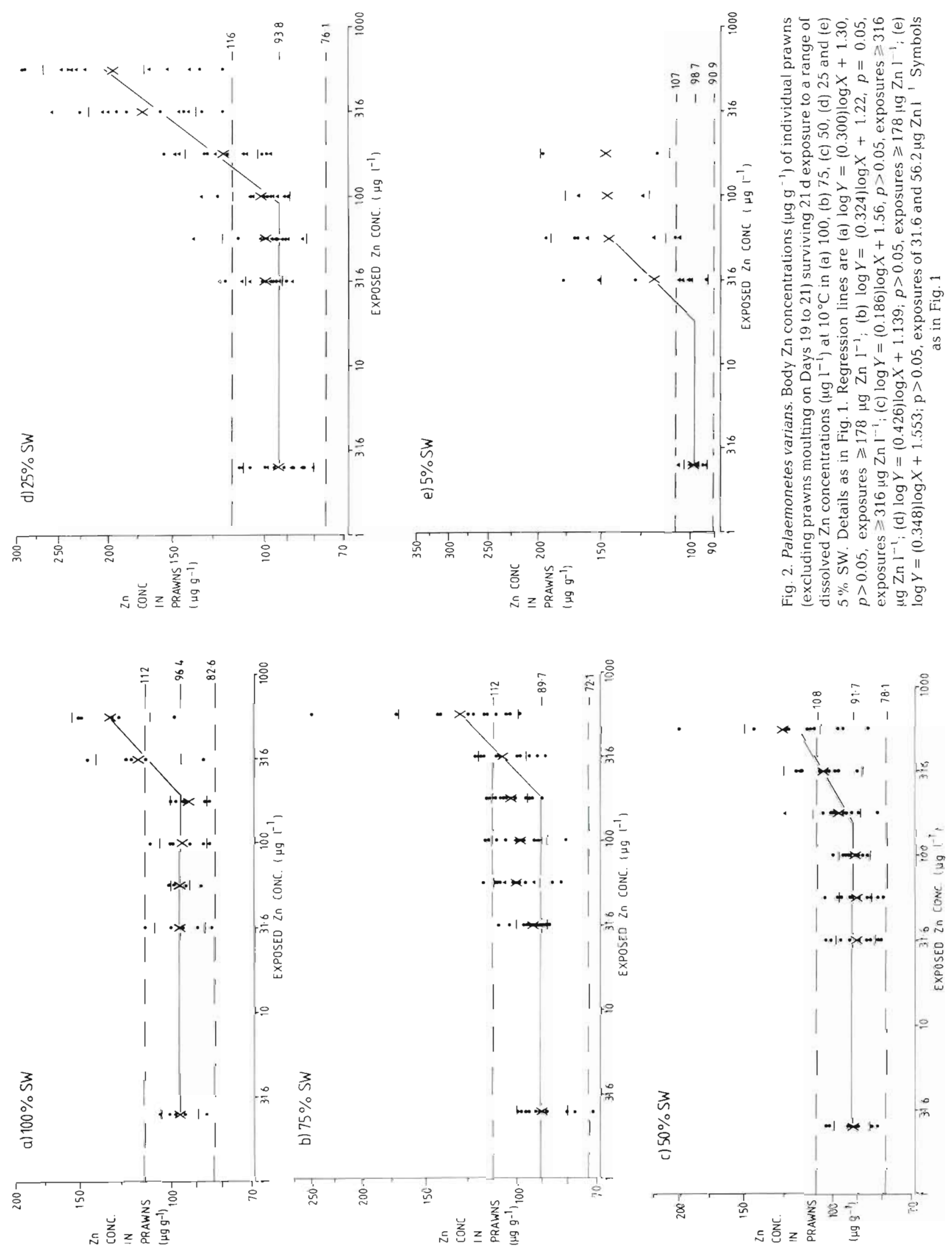
Table 2. Palaemon elegans and Palaemonetes varians. Number of surviving prawns with total body Zn concentrations above the upper regulation limit as a fraction (\%) of the total number of survivors (excluding those that moulted between Day 19 and 21 ) after $21 \mathrm{~d}$ in each $\mathrm{Zn}$ exposure in the experimental salinities at $10^{\circ} \mathrm{C}$

\begin{tabular}{|c|c|c|c|c|c|}
\hline \multirow{2}{*}{$\begin{array}{c}\text { Zn exposure conc } \\
\left(\mu g l^{-1}\right)\end{array}$} & \multicolumn{5}{|c|}{ Number of non-regulators as a fraction (\%) of total survivors } \\
\hline & $5 \% \mathrm{SW}$ & $25 \% \mathrm{SW}$ & $50 \% \mathrm{SW}$ & $75 \%$ SW & $100 \% \mathrm{SW}$ \\
\hline \multicolumn{6}{|l|}{ Palaemon elegans } \\
\hline 2.5 (control) & & $0 / 7(0)$ & $0 / 12(0)$ & $0 / 12(0)$ & $1 / 11(9)$ \\
\hline 31.6 & & $0 / 3(0)$ & $4 / 12(33)$ & $1 / 12(8)$ & $2 / 9(22)$ \\
\hline 56.2 & & $0 / 7(0)$ & $8 / 11(73)$ & $1 / 12(8)$ & $1 / 11(9)$ \\
\hline 100 & & $0 / 4(0)$ & $11 / 12(92)$ & $3 / 12(25)$ & $0 / 10(0)$ \\
\hline 178 & & $2 / 5(40)$ & $11 / 12(92)$ & $5 / 11(42)$ & $3 / 10(30)$ \\
\hline 316 & & $0 / 8(0)$ & $11 / 12(92)$ & $10 / 12(83)$ & $8 / 11(82)$ \\
\hline 562 & & $2 / 10(20)$ & $9 / 9(100)$ & $10 / 11(91)$ & $10 / 12(83)$ \\
\hline \multicolumn{6}{|l|}{ Palaemonetes varians } \\
\hline 2.5 (control) & $0 / 6(0)$ & $0 / 12(0)$ & $0 / 8(0)$ & $0 / 12(0)$ & $0 / 5(0)$ \\
\hline 31.6 & $2 / 8(25)$ & $1 / 11(9)$ & $0 / 9(0)$ & $0 / 12(0)$ & $1 / 5(20)$ \\
\hline 56.2 & $6 / 7(86)$ & $1 / 12(8)$ & $0 / 9(0)$ & $0 / 12(8)$ & $0 / 5(0)$ \\
\hline 100 & $2 / 2(100)$ & $2 / 12(17)$ & $0 / 9(0)$ & $2 / 12(17)$ & $0 / 6(0)$ \\
\hline 178 & $2 / 2(100)$ & $7 / 12(58)$ & $1 / 10(10)$ & $2 / 12(17)$ & $0 / 6(0)$ \\
\hline 316 & $1 / 1(100)$ & $12 / 12(100)$ & $3 / 9(33)$ & $4 / 12(33)$ & $3 / 5(60)$ \\
\hline 562 & $\mathrm{~N}$ & $12 / 12(100)$ & $6 / 10(60)$ & $8 / 11(73)$ & $5 / 5(80)$ \\
\hline N: no survivors & & & & & \\
\hline
\end{tabular}

Fig. 3. Palaemon elegans. Summary of the effect of a range of dissolved $\mathrm{Zn}$ concentrations $\left(\mu \mathrm{g} \mathrm{I}^{-1}\right)$ on body $\mathrm{Zn}$ concentrations $\left(\mu \mathrm{g} \mathrm{g}^{-1}\right)$ of prawns surviving $21 \mathrm{~d}$ exposure in one of 4 salinities $(100,75,50$ or $25 \% \mathrm{SW}$ ) at $10^{\circ} \mathrm{C}$ (excluding prawns moulting on Days 19 to 21). Regression lines are from Fig. 1. Horizontal lines are mean $\mathrm{Zn}$ concentrations of Control prawns at each salinity drawn to the point of intersection with the regression line in the 100,75 and $50 \%$ SW experiments. Arrows indicate the regulated range (see text) at each salinity
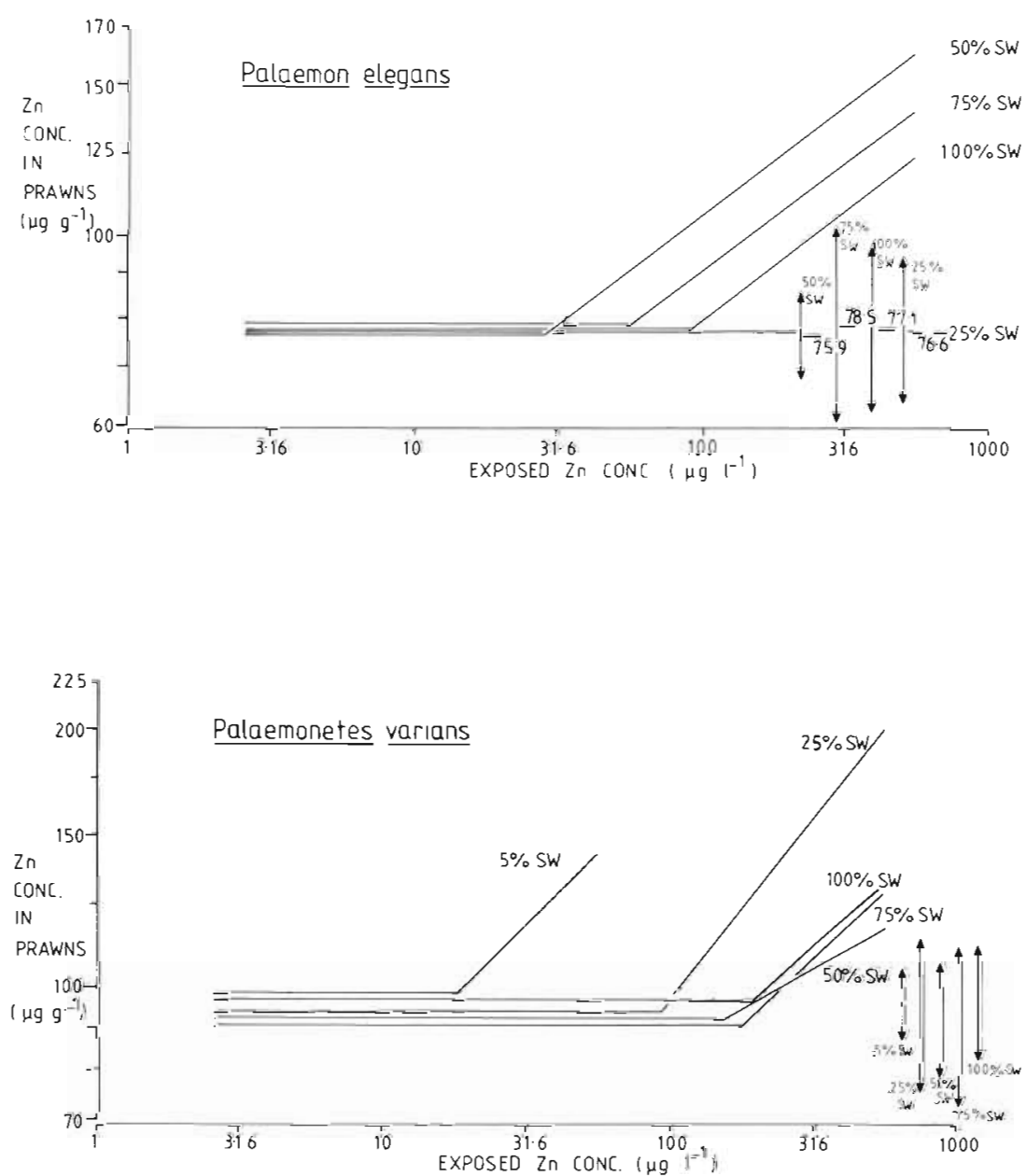

Fig. 4. Palaemonetes varians. Summary of the effect of a range of dissolved $\mathrm{Zn}$ concentrations $\left(\mu \mathrm{g}^{-1}\right)$ on body $\mathrm{Zn}$ concentrations $\left(\mu \mathrm{g}^{-1}\right.$ ) of prawns surviving $21 \mathrm{~d}$ exposure in salinities $100,75,50,25$ or $5 \% \mathrm{SW}$ at $10^{\circ} \mathrm{C}$ (excluding prawns moulting on Days 19 to 21). Regression lines are from Fig. 2. Details as for Fig. 3 
prawns survived exposure to higher concentrations at $5 \% \mathrm{SW}$ and all were non-regulators. Thresholds of regulation breakdown in 25 and $5 \%$ SW were 90 and $19 \mu \mathrm{g} \mathrm{Zn} \mathrm{l}^{-1}$ respectively. Therefore $\mathrm{Zn}$ regulation breakdown in $P$. varians clearly accurs at lower dissolved $\mathrm{Zn}$ concentrations with a decrease in salinity from $50 \%$ to $5 \% \mathrm{SW}$. There was less difference between dissolved $\mathrm{Zn}$ concentrations corresponding to the threshold of regulation breakdown over the salinity range 100 to $50 \%$ SW although the same trend with salinity was apparent.

\section{Mortality and moulting}

Mortalities of the 2 prawn species in the 5 experimental salinities are shown in Table 3 .

In Palaemon elegans, mortality was low at salinities down to $50 \%$ SW At the highest exposure concentration of $562 \mu \mathrm{g} \mathrm{Zn} 1^{-1}, 3$ prawns died in $50 \% \mathrm{SW}, 1$ in $75 \%$ SW and 0 in $100 \% \mathrm{SW}$, indicating increased toxicity of $\mathrm{Zn}$ to $P$, elegans at decreased salinities. In $25 \% \mathrm{SW}, 48 \%$ of the total number of experimental prawns died, including 5 of the 12 control prawns, a higher proportion than in the 2 highest $\mathrm{Zn}$ exposures. Therefore it appears that mortality of $P$. elegans increased in $25 \% \mathrm{SW}$ even in the absence of high $\mathrm{Zn}_{\mathrm{n}}$ concentrations. A large percentage of the mortalities occurred at or immediately after moulting (Table 3 ).

In Palaemonetes varians, there was high mortality in all $\mathrm{Zn}$ exposure concentrations in the 2 salinity extremes (i.e. 5 and $100 \% \mathrm{SW}$ ) and no or very low mortality in 25 and $75 \%$ SW Again many of the mortalities occurred during or immediately after moulting (Table 3).

In Palaemon elegans the proportion of moulters (Table 4) was high in 50 and $25 \%$ SW, suggesting that there is an increased frequency of moulting at lower salinities. Similarly in Palaemonetes varians a large proportion of the experimental prawns moulted in 25 and $5 \%$ SW (Table 4 ), while moulting was very infrequent in the higher salinities.

\section{Experiment 2: Palaemon elegans. Effect of salinity on Zn uptake}

The effects of different salinities on the rate of $\mathrm{Zn}$ uptake by Palaemon elegans were investigated at 2 exposure concentrations, (a) $56.2 \mu \mathrm{g} \mathrm{Zn} \mathrm{l^{-1 }}$ and (b) $100 \mu \mathrm{Zn} \mathrm{l}^{-1}$. Expt 2 (b) was extended to match the $21 \mathrm{~d}$ period used in the first experiment in an attempt to correlate rates of uptake in individual prawns with the presence/absence of regulation breakdown.

Table 3. Palaemon elegans and Palaemonetes varians. Mortality: no. of prawns that died as a fraction of the total exposed for up to $21 \mathrm{~d}$ in each $\mathrm{Zn}$ exposure concentration in each salinity regime, at $10^{\circ} \mathrm{C}$. No. of prawns that died at, or immediately after, moulting is shown in brackets. (P. elegans were not exposed to $5 \% \mathrm{SW}$ )

\begin{tabular}{|c|c|c|c|c|c|}
\hline \multirow{2}{*}{$\begin{array}{c}\text { Zn exposure conc. } \\
\left(\mu g l^{-1}\right)\end{array}$} & \multicolumn{5}{|c|}{ Salinity (\% SW) } \\
\hline & 5 & 25 & 50 & 75 & 100 \\
\hline \multicolumn{6}{|l|}{ Palaemon elegans } \\
\hline 2.5 (control) & & $5 / 12(4)$ & $0 / 12$ & $0 / 12$ & $0 / 12$ \\
\hline 31.6 & & $9 / 12(8)$ & $0 / 12$ & $0 / 12$ & $0 / 12$ \\
\hline 56.2 & & $5 / 12(4)$ & $1 / 12(1)$ & $0 / 12$ & $0 / 12$ \\
\hline 100 & & $8 / 12(7)$ & $0 / 12$ & $0 / 12$ & $0 / 12$ \\
\hline 178 & & $7 / 12(7)$ & $0 / 12$ & $1 / 12(0)$ & $0 / 12$ \\
\hline 316 & & $4 / 12(3)$ & $0 / 12$ & $0 / 12$ & $0 / 12$ \\
\hline 562 & & $2 / 12(2)$ & $3 / 12(3)$ & $1 / 12(1)$ & $0 / 12$ \\
\hline Mortality $[\%]$ & & $40 / 84(48 \%)$ & $4 / 84(5 \%)$ & $2 / 84(2 \%)$ & 0 \\
\hline No. dying at moult $(\%)$ & & $36 / 40(90 \%)$ & $4 / 4(100 \%)$ & $1 / 2(50 \%)$ & 0 \\
\hline \multicolumn{6}{|l|}{ Palaemonetes varians } \\
\hline 2.5 (control) & $6 / 12(2)$ & $0 / 12$ & $4 / 12(0)$ & $0 / 12$ & $7 / 12(0)$ \\
\hline 31.6 & $4 / 12(4)$ & $0 / 12$ & $3 / 12(0)$ & $0 / 12$ & $7 / 12(0)$ \\
\hline 56.2 & $5 / 12(3)$ & $0 / 12$ & $3 / 12(0)$ & $0 / 12$ & $7 / 12(0)$ \\
\hline 100 & $10 / 12(10)$ & $0 / 12$ & $3 / 12(1)$ & $0 / 12$ & $6 / 12(0)$ \\
\hline 178 & $10 / 12(8)$ & $0 / 12$ & $2 / 12(0)$ & $0 / 12$ & $6 / 12(0)$ \\
\hline 316 & $11 / 12(8)$ & $0 / 12$ & $3 / 12(1)$ & $0 / 12$ & $7 / 12(0)$ \\
\hline 562 & $12 / 12(9)$ & $0 / 12$ & $2 / 12(0)$ & $1 / 12(0)$ & $7 / 12(0)$ \\
\hline Mortality \% & $58 / 84(69 \%)$ & 0 & $20 / 84(24 \%)$ & $1 / 84(1 \%)$ & $47 / 84(56 \%)$ \\
\hline No. dying at moult $(\%)$ & $44 / 58(76 \%)$ & 0 & $2 / 20(10 \%)$ & 0 & 0 \\
\hline
\end{tabular}


Table 4. Palaemon elegans and Palaemonetes varians. Moulting: no. of prawns (out of 12 in every case) that moulted during the $21 \mathrm{~d}$ in each $\mathrm{Zn}$ exposure concentration in each salinity regime, at $10^{\circ} \mathrm{C}$. ( $P$. elegans were not exposed to $5 \% \mathrm{SW}$ )

\begin{tabular}{|c|c|c|c|c|c|}
\hline \multirow{2}{*}{$\begin{array}{c}\text { Zn exposure conc. } \\
\left(\mu g 1^{-1}\right)\end{array}$} & \multicolumn{5}{|c|}{ Salinity (\% SW) } \\
\hline & 5 & 25 & 50 & 75 & 100 \\
\hline \multicolumn{6}{|l|}{ Palaemon elegans } \\
\hline 2.5 (control) & & 4 & 7 & 1 & 3 \\
\hline 31.6 & & 10 & 5 & 3 & 6 \\
\hline 56.2 & & 5 & 8 & 5 & 1 \\
\hline 100 & & 7 & 7 & 4 & 4 \\
\hline 178 & & 10 & 8 & 2 & 7 \\
\hline 316 & & 3 & 11 & 4 & 5 \\
\hline 562 & & 2 & 9 & 3 & 4 \\
\hline Total & & $41(49 \%)$ & $55(65 \%)$ & $22(26 \%)$ & $30(36 \%)$ \\
\hline $\begin{array}{l}\text { No. of moulters } \\
\text { dying at moult }(\%)\end{array}$ & & $36(88 \%)$ & $4(7 \%)$ & $1(5 \%)$ & 0 \\
\hline \multicolumn{6}{|l|}{ Palaemonetes varians } \\
\hline 2.5 (control) & 7 & 5 & 0 & 0 & 0 \\
\hline 31.6 & 9 & 6 & 0 & 1 & 0 \\
\hline 56.2 & 6 & 9 & 0 & 2 & 0 \\
\hline 100 & 12 & 8 & 1 & 1 & 0 \\
\hline 178 & 8 & 7 & 1 & 0 & 0 \\
\hline 316 & 9 & 5 & 2 & 0 & 0 \\
\hline 562 & 9 & 9 & 0 & 0 & 0 \\
\hline Total & $60(71 \%)$ & $49(58 \%)$ & $4(5 \%)$ & $4(5 \%)$ & 0 \\
\hline $\begin{array}{l}\text { No. of moulters } \\
\text { dying at moult ( } \%)\end{array}$ & $44(73 \%)$ & 0 & $2(50 \%)$ & 0 & 0 \\
\hline
\end{tabular}

\section{Expt $2 \mathrm{a}$}

Counting of water samples for $\mathrm{Zn}-65$ confirmed that the dissolved $\mathrm{Zn}$ concentrations remained within $5 \%$ of the declared value of $56.2 \mu \mathrm{g} \mathrm{Zn}^{-1}$ in all tanks $(25,50$, $75,100 \% \mathrm{SW}$ ) throughout the $4 \mathrm{~d}$ experiment.

Prawns were exposed to $56.2 \mu \mathrm{g}^{-1}$ labelled $\mathrm{Zn}$ at each of the 4 salinities for $4 \mathrm{~d}$ at $10^{\circ} \mathrm{C}$. The accumula- tion of labelled $\mathrm{Zn}$ by individual prawns was followed over the $4 \mathrm{~d}$ period before prawns were analysed for total and labelled $\mathrm{Zn}$.

Analysis of variance confirmed that there was no significant difference $(p>0.05)$ between any mean $\mathrm{Zn}$ body concentration of Initial prawns acclimated to each of the 4 salinities for $3 d$, of Control prawns held at each of the 4 salinities for a further $4 \mathrm{~d}$ and of experimental
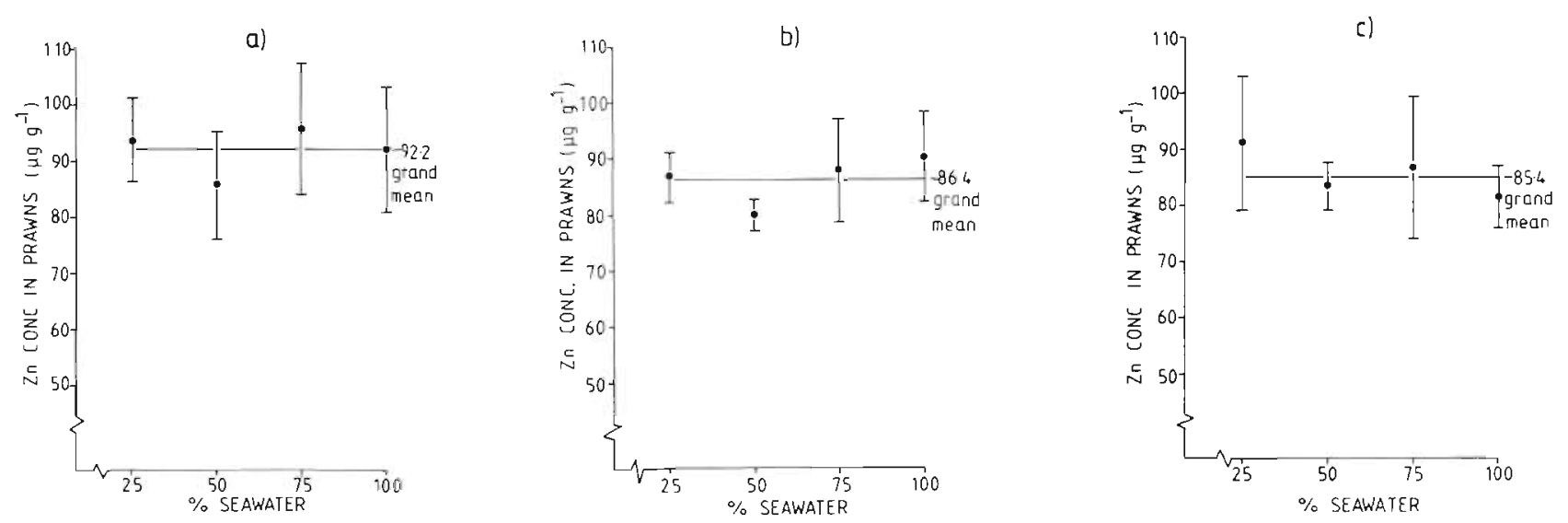

Fig. 5. Palaemon elegans. Mean total Zn concentrations ( $\left.\mu \mathrm{g} \mathrm{g}^{-1}\right)$ of (a) initial prawns after $3 \mathrm{~d}$ acclimation to one of 4 salinities (\% $\mathrm{SW}$ ) at $10^{\circ} \mathrm{C}$, (b) Control prawns held for a further $4 \mathrm{~d}$ at one of 4 experimental salinities (\% SW) at $10^{\circ} \mathrm{C}$, and (c) experimental prawns exposed to $56.2 \mu \mathrm{g}$ labelled $\mathrm{Zn} \mathrm{l}^{-1}$ for a further $4 \mathrm{~d}$ at one of 4 experimental salinities $(\% \mathrm{SW})$ at $10^{\circ} \mathrm{C}$. Horizontal lines denote grand means calculated for all 4 groups 
prawns exposed to $56.2 \mu \mathrm{g} \mathrm{Zn}^{-1}$ at each of the 4 salinities for the $4 \mathrm{~d}$ period (Fig. 5). Therefore it can be concluded that total body $\mathrm{Zn}$ concentrations of Palaemon elegans were regulated over the $4 \mathrm{~d}$ experimental period at all experimental salinities. Any nonregulator in the $50 \%$ salinity (cf. Fig. 1c) would probably be undetectable, given the short exposure period, in which little if any net $\mathrm{Zn}$ accumulation would occur.

Rates of uptake of labelled $\mathrm{Zn}$ by individual prawns and the concentration of labelled $\mathrm{Zn}$ passively adsorbed onto the surface of each prawn were calculated using the model curve described by Nugegoda \& Rainbow (1988).

Results are presented in Tables 5 and 6 . The rates of Zn uptake showed great individual variability even within the same experimental salinity (Table 5). A log transformation was used to normalize the data and the mean rates of $\mathrm{Zn}$ uptake by Palaemon elegans in different salinities were compared by a posteriori analysis of variance. There was no significant difference between the mean rate of uptake $(p>0.05)$ in $100 \%$ SW and $75 \%$ SW but these rates were significantly lower $(p=$ $0.01)$ than the rates of uptake in 50 and $25 \%$ SW The rate of $\mathrm{Zn}$ uptake decreased with salinity and a significant $(p=0.04)$ linear regression could be plotted for
Table 5. Palaemon elegans. Mean rates of $\mathrm{Zn}$ uptake by prawns exposed to $56.2 \mathrm{\mu g}$ labelled $\mathrm{Zn} \mathrm{l}^{-1}$ in each experimental salinity for $4 \mathrm{~d}$ at $10^{\circ} \mathrm{C}$

\begin{tabular}{|c|c|c|c|c|}
\hline & $\begin{array}{l}25 \% \\
\text { SW }\end{array}$ & $\begin{array}{l}50 \% \\
\text { SW }\end{array}$ & $\begin{array}{l}75 \% \\
\text { SW }\end{array}$ & $\begin{array}{c}100 \% \\
\text { SW }\end{array}$ \\
\hline $\begin{array}{l}\text { Mean rate Zn uptake } \\
\left(\mu g g^{-1} d^{-1}\right)\end{array}$ & 1.054 & 0.991 & 0.780 & 0.735 \\
\hline Standard deviation & 0.385 & 0.156 & 0.185 & 0.077 \\
\hline$n$ & 9 & 12 & 11 & 9 \\
\hline
\end{tabular}

the rate of Zn uptake versus salinity (as \% SW) of the medium (Fig. 6a).

The uptake of $\mathrm{Zn}$ at $56.2 \mu \mathrm{g} \mathrm{Zn} \mathrm{l^{-1 }}$ therefore is increased in $25 \%$ SW in comparison with uptake rates at higher salinities, and an even greater increase in the rate of uptake could be expected at higher exposed $Z_{n}$ concentrations. Therefore in Expt 1 , when Palaemon elegans was exposed to 178,316 and $562 \mu \mathrm{g} \mathrm{Zn} \mathrm{l}^{-1}$ in $25 \%$ SW, the excess $\mathrm{Zn}$ expected to have been accumulated must necessarily have been lost within the $21 \mathrm{~d}$ period. Thus the absence of net $\mathrm{Zn}$ accumulation in prawns in the high exposure at $25 \%$ SW was evidently not a result of prevention of entry of $\mathrm{Zn}$ into

Table 6. Palaemon elegans. Mean concentrations of labelled Zn estimated to be initially adsorbed onto the surface of prawns exposed to $56.2 \mu \mathrm{g}$ labelled $\mathrm{Zn} 1^{-1}$ in each experimental salinity for $4 \mathrm{~d}$ at $10^{\circ} \mathrm{C}$

\begin{tabular}{|lcccc|}
\hline & $25 \%$ SW & $50 \%$ SW & $75 \%$ SW & $100 \%$ SW \\
\hline Mean conc. adsorbed labelled Zn $\left(\mu^{\prime} g^{-1}\right)$ & 0.375 & 0.274 & 0.239 & 0.231 \\
Standard deviation & 0.093 & 0.052 & 0.054 & 0.098 \\
$n$ & 9 & 12 & 11 & 9 \\
Mean total Zn conc. $\left(\mu \mathrm{g} \mathrm{g}^{-1}\right)$ & 91.0 & 83.5 & 86.7 & 81.4 \\
Adsorbed conc. of labelled Zn as \% total Zn conc. & 0.41 & 0.33 & 0.28 & 0.28 \\
\end{tabular}
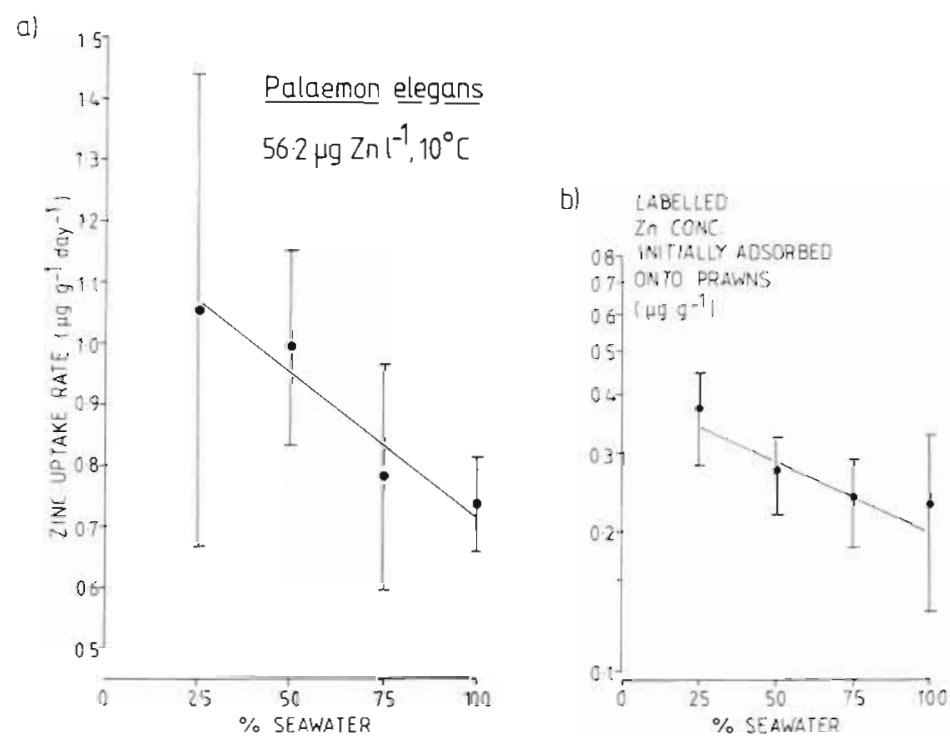

Fig. 6. Palaemon elegans. (a) Mean rates of $\mathrm{Zn}$ uptake ( $\mu \mathrm{g} \mathrm{g}^{-1} \mathrm{~d}^{-1}$ ) and (b) mean labelled $\mathrm{Zn}$ concentrations $\left(\mu \mathrm{g} \mathrm{g}^{-1}\right.$ ) initially adsorbed on to the body surface of prawns exposed to $56.2 \mathrm{ug}$ labelled $\mathrm{Zn} \mathrm{1^{-1 }}$ for $4 \mathrm{~d}$ in one of 4 salinities at $10^{\circ} \mathrm{C}$. Vertical lines indicate $\pm 1 \mathrm{SD}$ on either side of the means. (a) Regression line $(Y=-0.0048 X+1.881, p=0.04)$ describes the change of Zn uptake: rate with change in salinity (as \% SW); (b) regression line $(\log Y=$ $-0.0031 X+0.390, p=0.04$ ) describes the loglinear relation of the change in initially adsorbed labelled Zn concentration with change in salinity (as $\%$ SW) 
the body but the result of an increased efflux of $\mathrm{Zn}$ in $25 \%$ SW

The mean initial adsorption of labelled $\mathrm{Zn}$ also increased with decrease in salinity although there was great variability between individual prawns even within the same experimental salinity (Table 6). A significant inverse log-linear regression could be plotted of the concentration of $\mathrm{Zn}$ initially adsorbed versus the salinity of the medium (Fig. 6b).

\section{Expt $2 b$}

Counting of water samples for $\mathrm{Zn}-65$ confirmed that dissolved $\mathrm{Zn}$ concentrations were maintained within $5 \%$ of the declared concentration of $100 \mu \mathrm{g} \mathrm{ZnI^{-1 }}$

The total $\mathrm{Zn}$ concentrations of individual prawns surviving exposure to $100 \mu \mathrm{g} \mathrm{l}^{-1}$ labelled $\mathrm{Zn}$ for $21 \mathrm{~d}$ in 100 and $50 \%$ SW and in Control prawns held for $21 \mathrm{~d}$ in 100 and $50 \%$ SW with no added $\mathrm{Zn}$ are shown in Fig. 7. The mean $\mathrm{Zn}$ concentrations of Initial prawns acclimated to either salinity for $3 \mathrm{~d}$ (also shown in Fig. 7) did not differ significantly from each other nor from mean Zn concentrations of Controls at the 2 salinities.

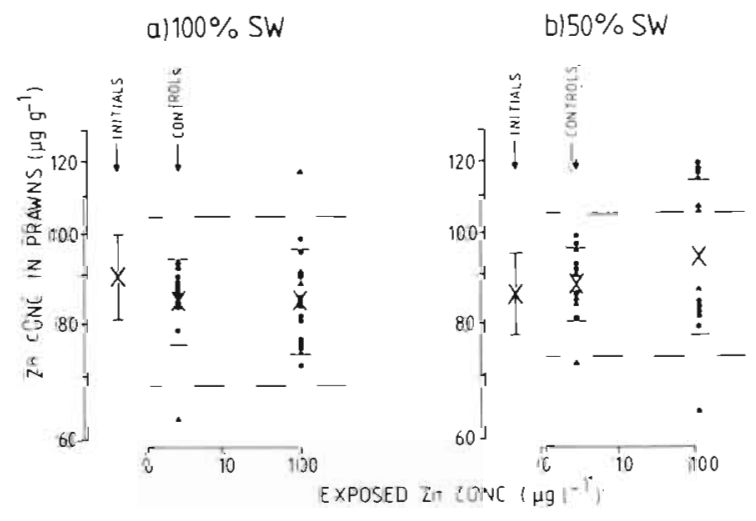

Fig. 7. Palaemon elegans. Total body $\mathrm{Zn}$ concentrations $(\mu \mathrm{g}$ $\mathrm{g}^{-1}$ ) of Initial prawns (mean $\pm 1 \mathrm{SD}$ ), Control prawns, and prawns surviving exposure to $100 \mu \mathrm{g}$ labelled $\mathrm{Zn} 1^{-1}$ for $21 \mathrm{~d}$ in (a) $100 \% \mathrm{SW}$, (b) $50 \% \mathrm{SW}$ at $10^{\circ} \mathrm{S}$. Symbols: (4) prawns that moulted during the experiment; ( $\bullet$ non-moulters. Short horizontal lines: sample means $\pm 1 \mathrm{SD}$. The regulated range (mean zinc concentration $\pm 1.96 \mathrm{SD}$ of Controls, transformed data) is limited by dashed lines

Limits of prawn $\mathrm{Zn}$ regulation were again defined as the Control mean $\mathrm{Zn}$ concentration \pm 1.96 SD (logtransformed data) for each salinity, and all prawns with body concentrations greater than the upper regulation limit were identified as having shown further net accumulation (non-regulators). Five of 13 survivors showed further net accumulation of $\mathrm{Zn}$ when exposed to $100 \mu \mathrm{g} \mathrm{Zn} l^{-1}$ in $50 \% \mathrm{SW}$ while only $1 / 16$ survivors did not regulate total body $\mathrm{Zn}$ concentrations at the same exposed concentration in $100 \%$ SW (Fig. 7). This is supportive evidence for the conclusion reached earlier that Palaemon elegans shows increasing breakdown in $Z n$ regulation at a defined exposure concentration at decreasing salinities, down to $50 \% \mathrm{SW}$. Nevertheless the mean total $\mathrm{Zn}$ concentration of prawns exposed to elevated dissolved $\mathrm{Zn}$ in 100 and $50 \%$ SW were not significantly different to that of the Controls in each salinity.

The concentration of labelled $\mathrm{Zn}$ in each prawn was plotted for all individuals as shown in the examples in Fig. 8. The data show a high accumulation of labelled

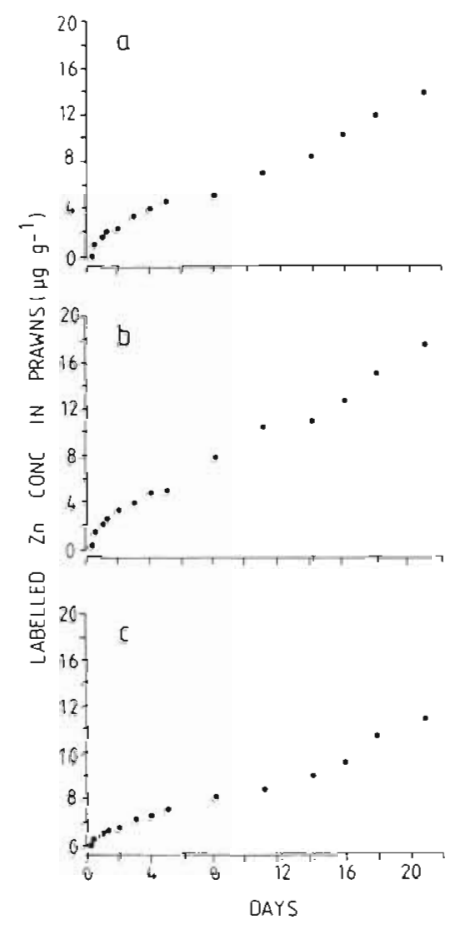

Fig. 8. Palaemon elegans. The accumulation of labelled $\mathrm{Zn}$ by 3 individual prawns $(\mathrm{a}, \mathrm{b}, \mathrm{c})$ exposed to $100 \mu \mathrm{g}$ labelled $\mathrm{Zn} \mathrm{l}^{-1}$ in $100 \% \mathrm{SW}$ for $21 \mathrm{~d}$ at $10^{\circ} \mathrm{C}$

Zn with a tendency toward asymptotic values at ca 3 to $4 \mathrm{~d}$. After about $4 \mathrm{~d}$ in all cases the accumulation of labelled $\mathrm{Zn}$ further increased above the apparent asymptote until the last sampling point (Day 21). In many cases the $6 \mathrm{~h}$ data point was low, probably indicative of as yet incomplete initial adsorption; $6 \mathrm{~h}$ data points were therefore excluded from all further analyses.

Curves were fitted to the data up to the $3 \mathrm{~d}$ data point (excluding the low $6 \mathrm{~h}$ point), using the model applied earlier (Nugegoda \& Rainbow 1988), and individual rates of $\mathrm{Zn}$ uptake calculated. Mean uptake rates $( \pm 1$ $\mathrm{SD})$ in Palaemon elegans exposed to $100 \mu \mathrm{g} \mathrm{Zn} \mathrm{l}^{-1}$ at $10^{\circ} \mathrm{C}$ were $5.27 \pm 3.67(n=19)$ and $2.39 \pm 0.84(n=$ 14) $\mu \mathrm{gn} \mathrm{g}^{-1} \mathrm{~d}^{-1}$ in 50 and $100 \% \mathrm{SW}$ respectively. The mean uptake rate by prawns in $50 \%$ SW was signifi- 
cantly greater than that of prawns in $100 \% \mathrm{SW}(p=$ 0.006 ) in spite of the great individual variability at each salinity.

As would be expected from the data shown in Fig. 1c,

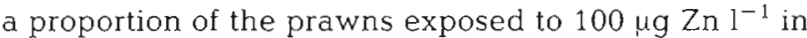
$50 \% \mathrm{SW}$ for $21 \mathrm{~d}$ at $10^{\circ} \mathrm{C}$ had suffered breakdown of regulation of body $\mathrm{Zn}$ concentration. [The accumulation of labelled $\mathrm{Zn}$ after the apparent asymptote at ca $3 d$, as exemplified in Fig. 8, is further complicated in such prawns suffering $\mathrm{Zn}$ regulation breakdown (only in the $50 \%$ SW experiment) because total body concentrations would have continuously increased after regulation breakdown. In regulators - all prawns in $100 \% \mathrm{SW}$ in Expt $2 \mathrm{~b}$ (except 1 moulter) including those depicted in Fig. 8 - the increasing concentration of labelled $\mathrm{Zn}$ replaced original unlabelled $\mathrm{Z}_{\mathrm{n}}$ already present with no change in total $\mathrm{Zn}$ concentration.]

There was a significant difference $(p=0.01)$ between mean $\mathrm{Zn}$ uptake rates of regulators and nonregulators of the prawns exposed to $50 \%$ SW in Expt $2 b$ (Fig. 9). Again therefore there is a correlation between high $\mathrm{Zn}$ uptake rate and regulation breakdown.

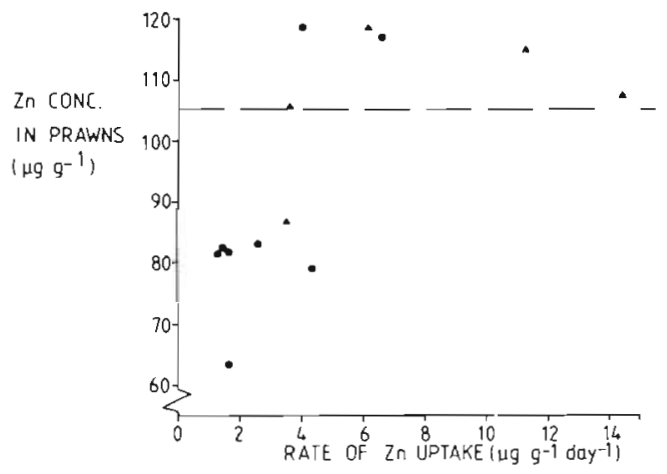

Fig. 9. Palaemon elegans. Total body $\mathrm{Zn}$ concentrations ( $\mu \mathrm{g}$ $\left.\mathrm{g}^{-1}\right)$ plotted against $\mathrm{Zn}$ uptake rates $\left(\mu \mathrm{g} \mathrm{g}^{-1} \mathrm{~d}^{-1}\right)$ of individual prawns exposed to $100 \mu \mathrm{g} \mathrm{Zn} \mathrm{I} \mathrm{I}^{-1}$ for $21 \mathrm{~d}$ in $50 \% \mathrm{SW}$ at $10^{\circ} \mathrm{C}$ Dashed line denotes the defined upper regulation limit and thereby separates regulators and non-regulators. Symbols: (A) prawns that moulted between 3 and $19 \mathrm{~d} ;(\bullet)$ non-moulters

The mean labelled $\mathrm{Zn}$ concentration initially adsorbed onto the bodies of prawns exposed to $100 \mu \mathrm{g}$ $\mathrm{Zn} 1^{-1} 50 \% \mathrm{SW}$ was higher than that of prawns exposed to $100 \mu \mathrm{g} \mathrm{Zn} 1^{-1}$ in $100 \% \mathrm{SW}$ (Table 7 ).

Table 8 provides data on mortality and moulting in Expt 2b. An increase in $\mathrm{Zn}$ uptake rate soon after moulting was clearly observed in all individuals that moulted in Expt 2b. Four of 6 prawns that showed breakdown in $\mathrm{Zn}$ regulation in $50 \% \mathrm{SW}$ were moulters, and the only non-regulator in $100 \%$ SW similarly had moulted. Therefore at low salinities the added increase in the uptake rate after moulting resulted in prawns being unable to match excretion to uptake.
Table 7 Palaemon elegans. Concentrations of labelled $\mathrm{Zn}$ estimated as initially adsorbed onto the surface of prawns exposed to $100 \mu \mathrm{g}$ labelled $\mathrm{Zn} \mathrm{l}^{-1}$ for $21 \mathrm{~d}$ in each salinity regime at $10^{\circ} \mathrm{C}$

\begin{tabular}{|lcc|} 
& \multicolumn{2}{c|}{ Salinity } \\
& $50 \%$ SW & $100 \% \mathrm{SW}$ \\
\hline Mean conc. adsorbed labelled & & \\
$\mathrm{Zn}\left(\mu \mathrm{g} \mathrm{g}^{-1}\right)$ & 0.457 & 0.210 \\
Standard deviation & 0.709 & 0.213 \\
$n$ & 19 & 15 \\
\hline
\end{tabular}

Experiment 3: Palaemonetes varians. Effect of salinity on Zn uptake

Palaemonetes varians were exposed to $100 \mu \mathrm{g} \mathrm{l}^{-1}$ labelled $\mathrm{Zn}$ at either $50 \%$ or $25 \%$ SW either after acclimation for $15 \mathrm{~d}$ to $50 \% \mathrm{SW}$ (Expt 3a) or after acclimation for $15 \mathrm{~d}$ to the appropriate salinity $(50 \%$ or $25 \%$ SW) (Expt 3b).

Counting of labelled $\mathrm{Zn}$ in water samples showed that $\mathrm{Zn}$ concentrations remained within $7 \%$ of the declared concentration of $100 \mu \mathrm{g} \mathrm{Zn} \mathrm{^{-1 }}$ throughout the experiments

\section{Total $\mathrm{Zn}$ concentrations in prawns}

Table 9 shows the mean total $\mathrm{Zn}$ concentrations of Initial prawns acclimated to $50 \%$ SW for $15 \mathrm{~d}$ in Expt $3 a_{1}$ of Initial prawns acclimated to $50 \%$ or $25 \%$ SW in Expt $3 b$, and of Control prawns in both experiments held for $71 \mathrm{~h}$ at $50 \% \mathrm{SW}$ or $25 \%$ SW. Mean total $\mathrm{Zn}$ concentrations in experimental prawns exposed to 100 ug labelled $\mathrm{Zn} \mathrm{I}{ }^{-1}$ for $71 \mathrm{~h}$ are also shown. Analysis of variance revealed no significant differences in the mean $\mathrm{Zn}$ concentrations of prawns in all tabulated groups.

Thus there was no change in regulated (Control) Zn concentration between prawns held at either $25 \%$ or $50 \%$ for $71 \mathrm{~h}$ after $15 \mathrm{~d}$ acclimation to $50 \% \mathrm{SW}$ (Table 9b). Similarly there was no change in regulated (Control) $Z_{n}$ concentration between prawns held at either $25 \%$ or $50 \%$ SW for up to $24 \mathrm{~d}$ (Table 9a). Similarly $71 \mathrm{~h}$ exposure to $100 \mu \mathrm{g} \mathrm{Zn} \mathrm{l^{-1 }}$ did not cause any change in prawn zinc concentration at $25 \%$ SW or $50 \%$ SW, any net accumulation of body $\mathrm{Zn}$ at $25 \%$ SW (possible in a proportion of exposed Palaemonetes varians - see Fig. 2 d) being insignificant in the time period. Pre-exposure of prawns to $15 \mathrm{~d}$ at $25 \%$ or $50 \%$ SW did not affect subsequent accumulation in $25 \% \mathrm{SW}$ i.e. accumulation history had no effect on $\mathrm{Zn}$ accumulation in $25 \% \mathrm{SW}$ (Table 9b) 
Table 8. Palaemon elegans. Mortality and moulting. No. of Control and experimental prawns that died (\%) and moulted (\%) during exposure to $100 \mu \mathrm{g} \mathrm{Zn} \mathrm{l^{-1 }}$ in $100 \% \mathrm{SW}$ or $50 \% \mathrm{SW}$ for $21 \mathrm{~d}$ at $10^{\circ} \mathrm{C}$. Last column shows no. of prawns that died at or immediately after moulting

\begin{tabular}{|c|c|c|c|c|}
\hline Exposure & & $\begin{array}{c}\text { Mortality } \\
(\%)\end{array}$ & $\begin{array}{l}\text { No. of moulters } \\
(\%)\end{array}$ & $\begin{array}{l}\text { Deaths associated } \\
\text { with moulting }\end{array}$ \\
\hline $100 \% \mathrm{SW}$ & 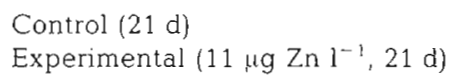 & $\begin{array}{l}1 / 12(8) \\
4 / 20(20)\end{array}$ & $\begin{array}{l}3 / 12(25) \\
4 / 20(20)\end{array}$ & $\begin{array}{l}1 \\
0\end{array}$ \\
\hline $50 \% \mathrm{SW}$ & 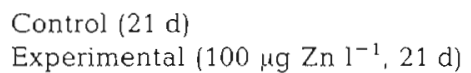 & $\begin{array}{l}1 / 12(8) \\
7 / 20(35)\end{array}$ & $\begin{array}{l}5 / 12(42) \\
5 / 20(25)\end{array}$ & $\begin{array}{l}1 \\
0\end{array}$ \\
\hline
\end{tabular}

Table 9. Palaemonetes varians. Expt 3: mean total body $\mathrm{Zn}$ concentrations ( $\mu \mathrm{g}^{-1} \pm 1 \mathrm{SD}$ ) of Initial and Control prawns and experimental prawns exposed to $100 \mu \mathrm{g}^{-1}$ labelled $\mathrm{Zn}$ for $71 \mathrm{~h}$ after (a) acclimation to $50 \% \mathrm{SW}$ only and (b) acclimation to the appropriate salinity, for $15 \mathrm{~d}$. $n$ : no. of samples

\begin{tabular}{|c|c|c|c|c|}
\hline $\begin{array}{l}\text { Acclimation } \\
\text { medium } \\
(15 \mathrm{~d})\end{array}$ & $\begin{array}{c}\text { Exposure } \\
\text { medium } \\
(71 \mathrm{~h})\end{array}$ & $\begin{array}{l}\text { Initials } \\
(n)\end{array}$ & $\begin{array}{l}\text { Controls } \\
\text { (n) }\end{array}$ & $\begin{array}{c}\text { Experimental } \\
\left(100 \mu \mathrm{g} \mathrm{Zn} l^{-1}\right) \\
(n)\end{array}$ \\
\hline \multicolumn{5}{|l|}{ (a) } \\
\hline \multirow[t]{2}{*}{$50 \% \mathrm{SW}$} & $25 \%$ SW & & $\begin{array}{c}100.3 \pm 11.4 \\
(15)\end{array}$ & $\begin{array}{c}103.4 \pm 10.4 \\
(15)\end{array}$ \\
\hline & & $94.1 \pm 1.07$ & & \\
\hline $50 \% \mathrm{SW}$ & $50 \% \mathrm{SW}$ & & $\begin{array}{c}97.3 \pm 10.8 \\
(15)\end{array}$ & $\begin{array}{c}103.1 \pm 11.4 \\
(15)\end{array}$ \\
\hline \multicolumn{5}{|l|}{ (b) } \\
\hline $25 \%$ SW & $25 \% \mathrm{SW}$ & $\begin{array}{c}96.1 \pm 9.5 \\
(12)\end{array}$ & $\begin{array}{l}89.2 \pm 10.3 \\
(15)\end{array}$ & $\begin{array}{c}103.0 \pm 12.9 \\
(15)\end{array}$ \\
\hline $50 \% \mathrm{SW}$ & $50 \% \mathrm{SW}$ & $\begin{array}{c}99.6 \pm 10.2 \\
(15)\end{array}$ & $\begin{array}{c}93.6 \pm 11.1 \\
(15)\end{array}$ & $\begin{array}{c}99.0 \pm 9.3 \\
(15)\end{array}$ \\
\hline
\end{tabular}

Zinc uptake

Fig. 10 shows examples of the pattern of labelled $\mathrm{Zn}$ accumulation by individual Palaemonetes varians exposed for $71 \mathrm{~h}$ to $100 \mu \mathrm{g} \mathrm{Zn} \mathrm{l}^{-1}$ at $50 \% \mathrm{SW}$, similar patterns being present when $P$. varians were exposed to $100 \mu \mathrm{g} \mathrm{Zn}^{-1}$ at $25 \%$ SW. As for Palaemon elegans, model curves were fitted to the data for individual prawns (Nugegoda \& Rainbow 1988). The fitted curves were significant $(p<0.05)$ in $92 \%$ of cases.

The rates of labelled $\mathrm{Zn}$ uptake in $100 \mu \mathrm{g} \mathrm{Zn} \mathrm{I}^{-1}$ by Palaemonetes varians with 2 different acclimation histories are presented in Table 10 . The mean uptake rate in $25 \%$ SW was significantly higher $(p<0.05)$ than that in $50 \% \mathrm{SW}$ in both experiments. There was no significant difference between mean uptake rates by $P$. varians in $50 \% \mathrm{SW}$ in both experiments: nor between mean uptake rates in $25 \%$ with or without acclimation to the salinity. It can be concluded that the rate of $\mathrm{Zn}$ uptake by Palaemonetes varians in $25 \% \mathrm{SW}$ is unaffected by prior acclimation for $15 \mathrm{~d}$ to $50 \% \mathrm{SW}$ as opposed to $25 \%$ SW.

There was a marked variability in the rate of $\mathrm{Zn}$ uptake in individual Palaemonetes varians. Uptake
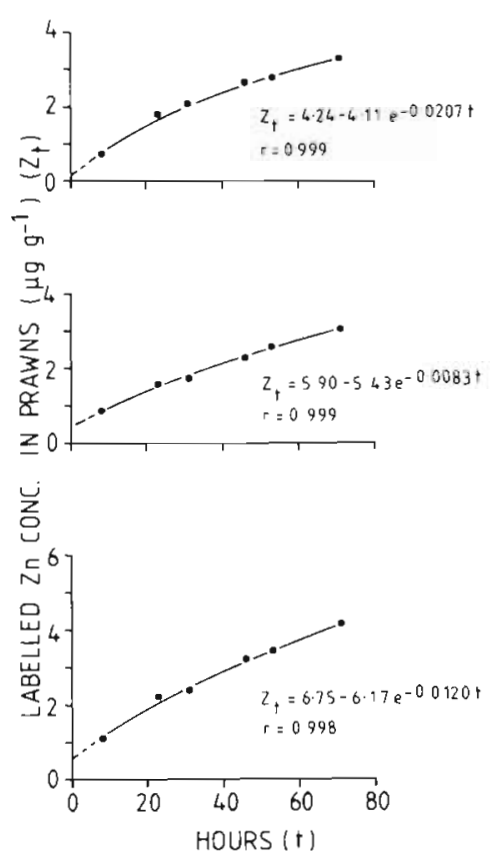

Fig. 10. Palaemonetes varians. Accumulation of labelled $\mathrm{Zn}$ $\left(Z_{t}, \mu \mathrm{g} \mathrm{g}^{-1}\right)$ by 3 individual prawns exposed to $100 \mu \mathrm{g}$ labelled $\mathrm{Zn} \mathrm{l}^{-1}$ for up to $71 \mathrm{~h}(\mathrm{t})$ in $50 \% \mathrm{SW}$ at $10^{\circ} \mathrm{C}$ after $15 \mathrm{~d}$ acclimation to $50 \% \mathrm{SW}$ The fitted curves are significant at $p<0.001$ 
Table 10. Palaemonetes varians. Mean rates of $\mathrm{Zn}$ uptake by individual prawns exposed to $100 \mu \mathrm{g} \mathrm{l^{-1 }}$ labelled $\mathrm{Zn}$ for $71 \mathrm{~h}$ at $10^{\circ} \mathrm{C}$ in either $50 \%$ SW or $25 \%$ SW after (a) acclimation for $15 \mathrm{~d}$ to $50 \%$ SW and (b) acclimation for $15 \mathrm{~d}$ to either $50 \%$ SW or $25 \%$ SW as appropriate

\begin{tabular}{|c|c|c|c|c|}
\hline $\begin{array}{l}\text { Acclimation } \\
\text { medium } \\
(15 \mathrm{~d})\end{array}$ & $\begin{array}{l}\text { Exposure } \\
\text { medium } \\
(71 \mathrm{~h})\end{array}$ & $\begin{array}{l}\text { Mean rate } \\
\text { Zn uptake } \\
\left(\mu g g^{-1} d^{-1}\right)\end{array}$ & $S D$ & No. \\
\hline \multicolumn{5}{|l|}{ (a) } \\
\hline $50 \% \mathrm{SW}$ & $25 \%$ SW & 3.19 & 1.09 & 14 \\
\hline $50 \% \mathrm{SW}$ & $50 \% \mathrm{SW}$ & 2.03 & 0.64 & 15 \\
\hline \multicolumn{5}{|l|}{ (b) } \\
\hline $25 \% \mathrm{SW}$ & $25 \% \mathrm{SW}$ & 3.47 & 1.60 & 13 \\
\hline $50 \% \mathrm{SW}$ & $50 \% \mathrm{SW}$ & 1.80 & 0.61 & 13 \\
\hline
\end{tabular}

rates were not related to the dry weights of prawns in any exposure.

There was no significant difference between the mean $\mathrm{Zn}$ concentrations ( $\mu \mathrm{g} g{ }^{1}$ ) estimated as initially adsorbed onto the body of Palaemonetes varians in $50 \% \mathrm{SW}(0.464 \pm 0.321, n=15)$ and $25 \%$ SW $(0.321 \pm$ $0.299, n=14)$.

Experiment 4: Palaemonetes varians. Efiect of acclimation to low salinities on total body $\mathrm{Zn}$ concentration

Results from the Expt 1 (Table 1) show that there is a transient rise in body $\mathrm{Zn}$ concentration of Palaemonetes varians transferred from $50 \%$ SW to 25 or $5 \% \mathrm{SW}$. Expt 4 was designed to delimit this concentration rise more narrowly.

Fig. 11 shows the mean total body $\mathrm{Zn}$ concentrations
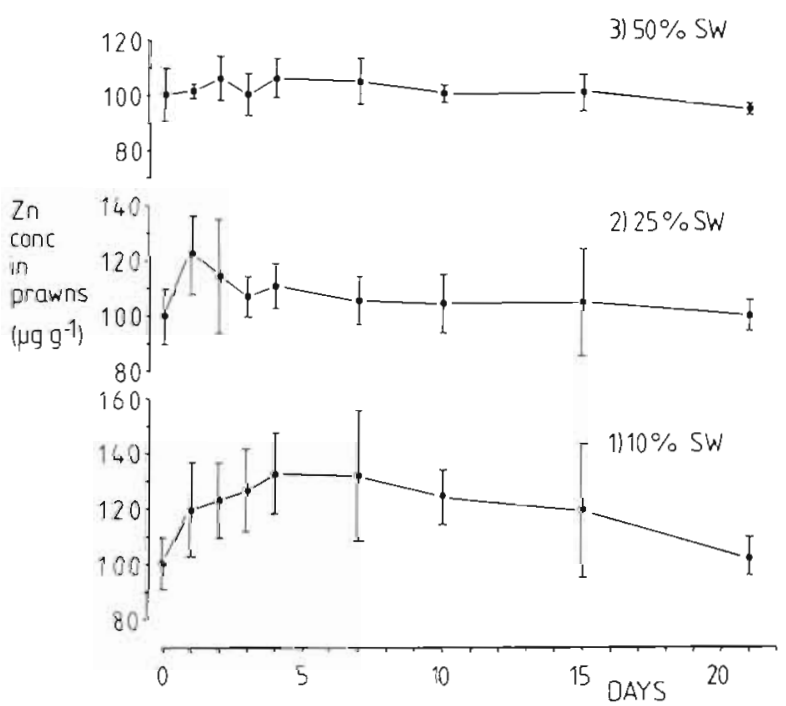

Fig. 11. Palaemonetes varians. Mean total body $\mathrm{Zn}$ concentrations $\left(\mu \mathrm{g} \mathrm{g}^{-1} \pm 1 \mathrm{SD}\right.$ ) in prawns sampled periodically throughout $21 \mathrm{~d}$ acclimation in (1) $10 \%$, (2) $25 \%$ and (3) $50 \%$ $\mathrm{SW}$. (Number of samples $=6$ in each case) in Palaemonetes varians held in 50,25 and $10 \% \mathrm{SW}$ with no added $\mathrm{Zn}$ for up to $21 \mathrm{~d}$, after being held in $50 \%$ SW since collection. Mean $\mathrm{Zn}$ concentration ( \pm 1 $\mathrm{SD}$ ) of the Initials (Day 0 for all salinities) was $99.6 \pm$ $10.2 \mu_{\mathrm{gg} \mathrm{g}}{ }^{-1}$

In $10 \% \mathrm{SW}$ there was a rise in total body $\mathrm{Zn}$ concentration of Palaemonetes varians over the first $4 \mathrm{~d}$, followed by a slow decrease. The mean $\mathrm{Zn}$ concentrations in prawns from Day 2 to Day 4 were significantly higher than that of Initial prawns (and of prawns in $50 \%$ SW at any sampling point). After $21 \mathrm{~d}$ the mean $\mathrm{Zn}$ concentration of the prawns did not differ significantly from that of Initial prawns.

In $25 \%$ SW a marked increase in body Zn concentration was evident after acclimation for $1 \mathrm{~d}$ and the mean body concentrations subsequently showed a trend towards decreasing concentration. Mean body $\mathrm{Zn}$ concentration did not change significantly during the $21 \mathrm{~d}$ acclimation in $50 \% \mathrm{SW}$. Analysis of variance showed no significant difference between the mean $\mathrm{Zn}$ concentrations of prawns after $21 \mathrm{~d}$ acclimation to the 3 salinities.

\section{Experiment 5: Palaemonetes varians. Regulation of body $\mathrm{Zn}$ in $50 \% \mathrm{SW}$ at $15^{\circ} \mathrm{C}$}

Total body Zn concentrations of Palaemonetes varians surviving $21 \mathrm{~d}$ exposure to a range of dissolved $\mathrm{Zn}$ concentrations in $50 \% \mathrm{SW}$ at the elevated temperature of $15^{\circ} \mathrm{C}$ are shown in Fig. 12. The mean $\mathrm{Zn}$ concentration in Initial prawns (103.9 $\left.\pm 9.3 \mu \mathrm{g} \mathrm{g}^{-1} \cdot n=10\right)$ was not significantly different from that of Controls $\left(103.3 \pm 6.2 \mu \mathrm{g} \mathrm{g}^{-1}, n=6\right)$. However, mean $\mathrm{Zn}$ concentrations in Initials and Controls from this experiment were significantly higher than mean Zn concentrations of Initials and Controls from the same experiment carried out at $10^{\circ} \mathrm{C}$ (Fig. 2C and Table 1). Both experiments were performed simultaneously on prawns from the same stock, and Initial and Control prawns had not 


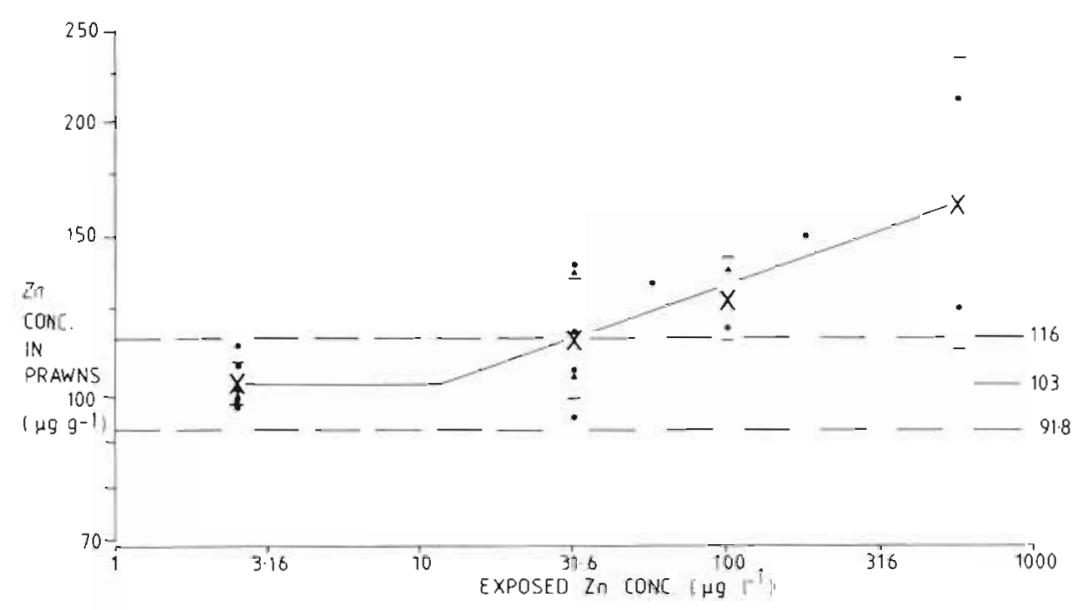

Fig. 12. Palaemonetes varians. Total body $\mathrm{Zn}$ concentrations $\left(\mu \mathrm{g} \mathrm{g}^{-1}\right)$ of prawns surviving $21 \mathrm{~d}$ exposure to the range of dissolved $\mathrm{Zn}$ concentrations $\left(\mu \mathrm{g}^{-1}\right)$ in $50 \% \mathrm{SW}$ at $15^{\circ} \mathrm{C}$. Details as for Fig. 1 . Regression $\operatorname{line}(\log Y=(0.117) \log X+1.890 ; p>0.05)$

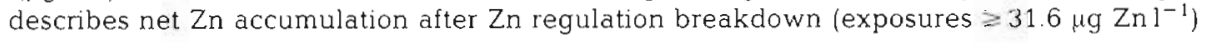

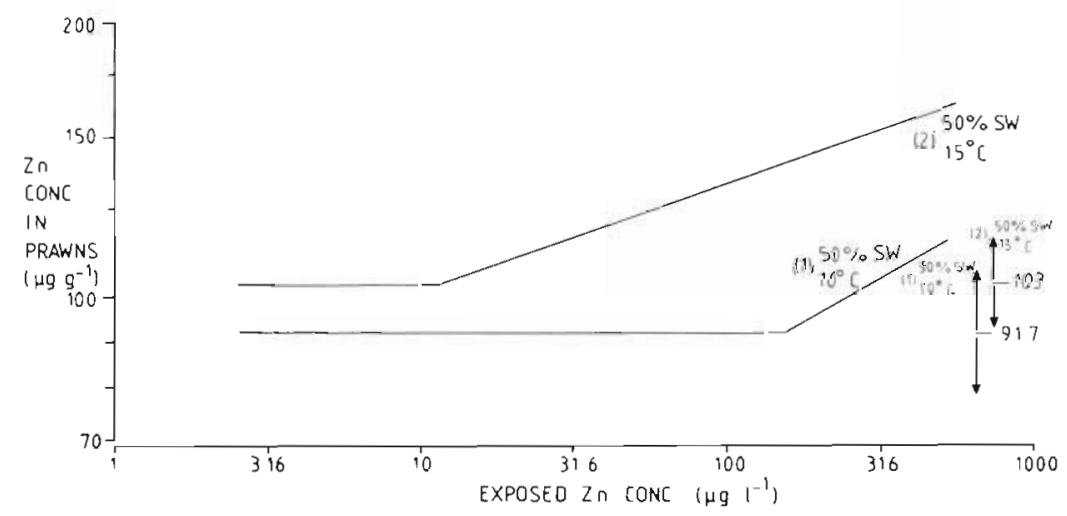

Fig. 13. Palaemonetes varians. Comparison of $\mathrm{Zn}$ regulation and further net $\mathrm{Zn}$ accumulation by prawns exposed to a range of dissolved $\mathrm{Zn}$ concentrations ( $\mu \mathrm{I}^{-1}$ ) in $50 \% \mathrm{SW}$ at $(1) 10^{\circ} \mathrm{C}$ and $(2) 15^{\circ} \mathrm{C}$. Regression lines are from Figs $2 \mathrm{C}$ and 12 . Details as for Fig. 3

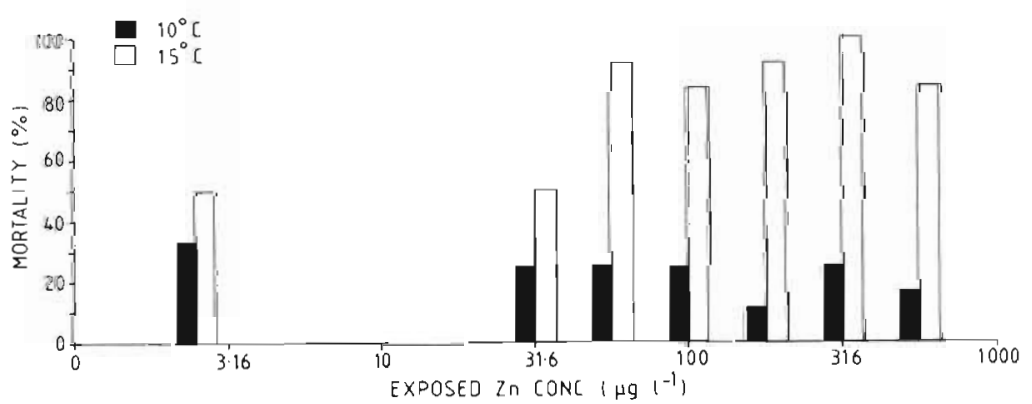

Fig. 14. Palaemonetes varians. Mortality: no. of prawns that died during the $21 \mathrm{~d}$ exposure as a percentage of the total number of prawns exposed to the range of dissolved $\mathrm{Zn}$ concentrations in $50 \% \mathrm{SW}$ at $10^{\circ}$ and $15^{\circ} \mathrm{C}$

been exposed to elevated dissolved $\mathrm{Zn}$ concentrations. This therefore shows that body $\mathrm{Zn}$ in $P$. varians is regulated at a higher concentration at $15^{\circ} \mathrm{C}$ than at $10^{\circ} \mathrm{C}$.

Fig. 13 compares $\mathrm{Zn}$ accumulation patterns at $10^{\circ} \mathrm{C}$ and $15^{\circ} \mathrm{C}$ and clearly shows that regulation breakdown occurs at a lower dissolved $\mathrm{Zn}$ exposure at the higher temperature.
Survival was very low in Palaemonetes varians exposed to elevated dissolved $\mathrm{Zn}$ concentrations at $15^{\circ} \mathrm{C}$. The mortality in each exposure has been plotted as a percentage in Fig. 14. Dissolved concentrations greater than $31.6 \mu \mathrm{g} \mathrm{Zn} \mathrm{l}^{-1}$ were more toxic to Palaemonetes varians in $50 \%$ at $15^{\circ} \mathrm{C}$ than at $10^{\circ} \mathrm{C}$, probably as a result of the inability of prawns to regulate total body $\mathrm{Zn}$ concentrations. 


\section{DISCUSSION}

It is known that Palaemon elegans is able to regulate the total body concentration of zinc over a range of dissolved $\mathrm{Zn}$ exposures in $100 \%$ seawater; when a threshold concentration of dissolved $\mathrm{Zn}$ is reached, regulation breaks down, and net $\mathrm{Zn}$ accumulation begins (White \& Rainbow 1982, 1984a, b, Nugegoda \& Rainbow 1987 1988). This study confirms that a similar pattern of $\mathrm{Zn}$ regulation below a threshold exposure is present when $P$. elegans is exposed to a range of dissolved concentrations in 75 and $50 \% \mathrm{SW}$. There is no change in level of the regulated $\mathrm{Zn}$ concentration with decreasing salinity, but the threshold $\mathrm{Zn}$ concentration at which regulation breaks down does decrease as salinity is reduced to $50 \% \mathrm{SW}$.

Similarly Palaemonetes varians regulates the body $Z n$ concentration to a constant level over a wide range of dissolved $\mathrm{Zn}$ concentrations in $100 \%$ SW until a threshold exposure is reached, regulation breaks down and net accumulation of body $\mathrm{Zn}$ begins. Similar accumulation patterns are seen for $P$. varians at salinities ranging through $100,75,50,25$ and $5 \%$ SW. The $\mathrm{Zn}$ concentration equivalent to the threshold of regulation breakdown decreases with reduction in salinity. There is a relatively small change over the salinity range $100 \%$ to $50 \%$ SW. As for Palaemon elegans there is no change in the regulated body $\mathrm{Zn}$ concentration of $P$, varians with decreasing salinity.

The rate of $\mathrm{Zn}$ uptake increases with decreasing salinity in both palaemonid species. In Palaemon elegans at least, regulation is brought about by the matching of the rate of $\mathrm{Zn}$ excretion to the rate of $\mathrm{Zn}$ uptake, this latter being affected by physico-chemical changes such as temperature (White \& Rainbow 1984a, Nugegoda \& Rainbow 1987) and the presence of the Zn chelating agent EDTA (Nugegoda \& Rainbow 1988). The results of this study can be interpreted by assuming that as the salinity is decreased (to $50 \% \mathrm{SW}$ in the case of $P$. elegans, to $5 \%$ SW in Palaemonetes varians), the rate of $\mathrm{Zn}$ uptake in the prawns is increased so that the maximum rate of $Z n$ excretion is exceeded at lower dissolved $Z n$ exposures. Similar interpretations explain for P. elegans: (1) the lowering of the dissolved $\mathrm{Zn}$ concentration corresponding to regulation breakdown with increased temperature (Nugegoda \& Rainbow 1987) as Zn uptake increases (White \& Rainbow 1984a); (2) the raising of the regulation breakdown exposure threshold in the presence of EDTA which reduces $\mathrm{Zn}$ uptake (Nugegoda \& Rainbow 1988)

The mechanism whereby changes in salinity affect heavy metal accumulation is not clear. Phillips (1976) suggested that effects of salinity may be due to changes in the ratio of major ions to heavy metals. Bryan \& Hummerstone (1973) suggested that the salinity effects on manganese uptake could be related to calcium availability and Wright (1977) considered that the uptake of cadmium by the shore crab Carcinus maenas might be related to the ambient calcium availability. The interpretation favoured here is that a decrease in salinity increases the proportion of the free uncomplexed metal ion in solution, this ion being the most bioavailable species of the metal for uptake by aquatic biota (Sunda et al. 1978, Engel \& Fowler 1979, Zamuda \& Sunda 1982, Florence 1983, Nugegoda \& Rainbow, 1988).

Mantoura et al. (1978) modelled the increase in concentration of $\mathrm{Zn}^{2+}$ over other species of $\mathrm{Zn} \mathrm{(e.g.} \mathrm{Zn-Cl}$ complexes) in seawater down the salinity gradient of an estuary. This model proposes a percentage increase of about $25 \%$ in the $\mathrm{Zn}^{2+}$ species with a decrease in salinity from $32 \mathrm{ppt}$ ( $47 \%$ of zinc as $\mathrm{Zn}^{2+}$ ) to $15 \mathrm{ppt}$. Therefore if the concentration of $\mathrm{Zn}^{2+}$ is the deciding factor in $Z_{n}$ uptake, a decrease in salinity would be expected to cause an increase in $\mathrm{Zn}$ uptake by an aquatic organism.

Results obtained with Palaemon elegans at $25 \%$ SW are at first sight inconsistent with the above interpretation of regulation breakdown. It has been confirmed that the uptake of $\mathrm{Zn}$ by Palaemon elegans was further raised as the salinity decreased to $25 \% \mathrm{SW}$, in line with interpretations of increased bioavailability of $\mathrm{Zn}$ in reduced salinities, but there was no expected regulation breakdown as at higher salinities. The conclusion drawn earlier was that the observed rise in $\mathrm{Zn}$ uptake in $25 \%$ SW must have been matched by increased $\mathrm{Zn}$ excretion, necessarily to a level not possible at comparable $\mathrm{Zn}$ exposures in higher salinities.

Palaemon elegans lives in littoral rockpools and Morris \& Taylor (1983) have presented physico-chemical data for pools of the Isle of Cumbrae, Firth of Clyde, from which the experimental prawns were collected. Salinities of $16 \mathrm{ppt}$ ( $50 \%$ SW) were not unusual in the rockpools but no salinities below $15 \mathrm{ppt}$ were recorded over a period of 1 yr (Morris \& Taylor 1983). P. elegans may therefore be adapted to cope with osmotic problems down to $50 \%$ SW (see also Ramirez de Isla Hernandez \& Taylor 1985) but a salinity of $25 \%$ SW may place the prawns under considerable osmotic stress. Taylor et al. (1985) for example showed that haemolymph calcium concentrations drop sharply in $P$. elegans in salinities lower than 10 ppt (31\% SW), indicating impairment of normal physiological and ionregulatory processes. In more dilute media there seems to be a marked decline in the regulation of calcium and chloride ions, and ion regulatory and osmoregulatory mechanisms increasingly break down (Panikkar 1941, Ramirez de Isla Hernandez \& Taylor 1985, Taylor et al. 1985). The observed increased mortality in $25 \% \mathrm{SW}$ supports this argument. Such increased mortality was 
apparently not an effect of the increased toxicity of $\mathrm{Zn}$ in $25 \%$ SW since $5 / 12$ prawns died in the Controls, this proportion being greater than the proportion of prawns $(2 / 12)$ that died in the highest exposure $\mathrm{Zn}$ concentration of $562 \mu \mathrm{g} \mathrm{Znl^{-1 }}$

Urine production by the antennary glands in palaemonids is increased at low salinities (Panikkar 1941, Parry 1955, Mantel \& Farmer 1983). It appears that in this very hypo-osmotic medium of $25 \% \mathrm{SW}$. Palaemon elegans undergoes a considerably raised osmotic uptake of water, balanced by a correspondingly large efflux of urine. The efflux of urine (isoosmotic with the haemolymph) would consist of water and dissolved salts (salt loss being compensated by increased active uptake of sodium ions in the gills) and the urine may act as an exit route for the excess $\mathrm{Zn}$ taken up. Whether or not the urine is routinely a major route for $Z n$ removal in $P$. elegans as in the lobster Homarus gammarus (vulgaris) (Bryan 1964), the rate of $\mathrm{Zn}$ efflux from prawns in $25 \%$ SW even in high $\mathrm{Zn}$ concentrations appears to be equal to or greater than Zn uptake.

The details of the decrease in $\mathrm{Zn}$ concentrations at the thresholds of regulation breakdown with reduction in salinity are different in Palaemonetes varians reflecting intrinsic differences between the 2 prawns. $P$. varians lives in brackish salt marsh pools and drainage channels. It is not found in full strength seawater in Britain (Parry 1955, Smaldon 1979) and can survive a lower range of salinities than Palaemon elegans. $P$. varians can therefore thrive in $25 \%$ SW and shows a more typical pattern of regulation and regulation breakdown at this salinity than does $P$. elegans. Parry (1955) showed that the rate of urine production in $P$. varians increased ca 6 times with changes in salinity from $50 \%$ to $25 \% \mathrm{SW}$, but presumably any increased $\mathrm{Zn}$ loss in the urine is inadequate to cope with the increased influx of $\mathrm{Zn}$ in exposed concentrations above $100 \mathrm{ug} \mathrm{Zn} \mathrm{l}^{-1}$ in $25 \% \mathrm{SW}$. The experiments involving $P$. varians at $5 \% \mathrm{SW}$ are more indicative of a prawn under osmotic stress with poor survivorship.

Adapted to a lower salinity range, Palaemonetes varians can be expected to have a more impermeable exoskeleton than Palaemon elegans (Mantel \& Farmer 1983). Indeed under the same conditions (100 $\mu \mathrm{g} \mathrm{Zn} \mathrm{l-1}$ in $50 \% \mathrm{SW})$, the $\mathrm{Zn}$ uptake rate of $P$. varians $(1.80 \pm$ $\left.0.61 \mu \mathrm{g} \mathrm{Zn} \mathrm{g} \mathrm{g}^{-1} \mathrm{~d}^{-1}\right)$ is significantly lower than that of $P$. elegans $\left(5.27 \pm 3.67 \mu \mathrm{g} \mathrm{Zn} \mathrm{g}^{-1} \mathrm{~d}^{-1}\right)$. Thus the rate of $\mathrm{Zn}$ uptake and pattern of $\mathrm{Zn}$ accumulation by the prawns at a particular salinity are a feature both of the extrinsic physico-chemical environment and of the intrinsic adaptations of the species concerned.

This study has confirmed earlier findings for Palaemon elegans (White \& Rainbow 1984a, b, Nugegoda \& Rainbow 1988) that there is considerable intraspecific variability in individual $\mathrm{Zn}$ uptake rates and correspondingly in individual thresholds of regulation breakdown. The same variability is applicable to Palaemonetes varians. Moreover, at least for Palaemon elegans, individual prawns with high rates of $\mathrm{Zn}$ uptake are more likely to show regulation breakdown, although maximum rates of $\mathrm{Zn}$ excretion will not necessarily vary between individual prawns in the same pattern.

In addition to intraspecific variability that may be genetically based (White \& Rainbow 1984b), variability in $\mathrm{Zn}$ uptake rates is also associated with the moulting cycle. Moulting causes a transient (up to $3 \mathrm{~d}$ ) increase in the total body $\mathrm{Zn}$ concentration of Palaemon elegans before regulatory mechanisms cause a return to a constant level (see also White \& Rainbow 1984a, b, Nugegoda \& Rainbow 1987, 1988). Many of the observed mortalities in experiments with both species were associated with moulting, presumably as a result of the toxic effects of such extra rapidly accumulated $\mathrm{Zn}$ concentrations.

The pattern of accumulation of labelled $\mathrm{Zn}$ by individual prawns of both species showed a tendency toward an asymptotic value (after ca 3 to $4 \mathrm{~d}$ in Palaemon elegans exposed to $100 \mu \mathrm{g} \mathrm{Zn}^{-1}$ in both 100 and $50 \%$ SW), beyond which accumulation continued to increase. The results indicate that $\mathrm{Zn}$ in the prawns is composed of at least 2 pools of $\mathrm{Zn}$ as predicted by the model of White \& Rainbow (1984a) for P. elegans. The apparent asymptote seen at ca $4 \mathrm{~d}$ is probably due to the rapidly exchanging pool of $\mathrm{Zn}$ (termed the 'fast pool') within the prawn, being almost totally exchanged with labelled $\mathrm{Zn}$ taken up from the medium. The uptake of labelled $\mathrm{Zn}$ into the pool or pools of $\mathrm{Zn}$ that exchange less rapidly with the environment (termed the 'slow pool[s]') could continue throughout the $21 \mathrm{~d}$ and predictably further if the experiment was not terminated, until $100 \%$ of the $\mathrm{Zn}$ within the prawn was exchanged for labelled $\mathrm{Zn}$. The slow pool would reach an asymptote only when all $\mathrm{Zn}$ within the prawn is labelled. This model is shown diagrammatically in Fig. 15.

There is an initial adsorption of labelled $\mathrm{Zn}$ onto the body of prawns placed in labelled media. This adsorption can be interpreted as having 2 components: (1) instantaneous adsorption onto unsaturated $\mathrm{Zn}$ binding sites on the cuticle surface, (2) passive isotopic exchange of unlabelled $\mathrm{Zn}$ already loosely bound onto cuticular surface with labelled $\mathrm{Zn}$ in the medium. The second process may be incomplete in many of the experimental prawns in this study after only $6 \mathrm{~h}$ and account for the apparently low $6 \mathrm{~h}$ count of labelled $\mathrm{Zn}$.

Regulated body $\mathrm{Zn}$ concentrations in both Palaemon elegans and Palaemonetes varians showed no longterm differences at different salinities. However at 


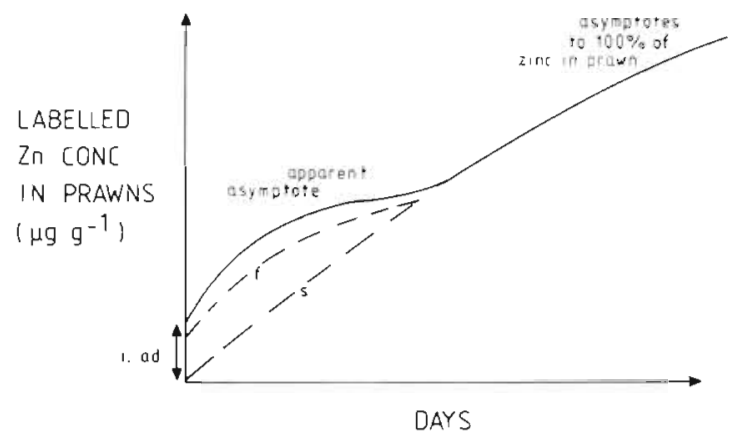

Fig. 15. Diagrammatic representation of the uptake of labelled $\mathrm{Zn}$ into prawns assuming that body $\mathrm{Zn}$ consists of 2 pools exchanging at different rates. f: uptake of labelled $\mathrm{Zn}$ into the 'fast' pool, s: uptake of labelled $\mathrm{Zn}$ into the 'slow' pool; i.ad. labelled $\mathrm{Zn}$ initially adsorbed onto prawns

salinities of $25 \%$ SW and below, $P$. varians showed a transient increase in body $\mathrm{Zn}$ concentration, which lasted less than a week at $10^{\circ} \mathrm{C}$ in $25 \% \mathrm{SW}$ but longer in lower salinities, in all cases being absent after $24 \mathrm{~d}$. In contrast, temperature increases cause a permanent rise in regulated $\mathrm{Zn}$ concentration in $P$. elegans (Nugegoda \& Rainbow 1987) and indeed P. varians, exposed to a range of salinities at $15^{\circ} \mathrm{C}$, regulated body $\mathrm{Zn}$ to a higher level than at $10^{\circ} \mathrm{C}$.

Such changes in regulated body $\mathrm{Zn}$ concentrations probably reflect metabolic needs (White \& Rainbow 1985, Rainbow 1988). Possible explanations for the initial increase in body $\mathrm{Zn}$ levels in Palaemonetes varians transferred to low salinity media include a temporary increase in haemocyanin levels, following the hypothesis that haemocyanin serves as a store for free amino acids required at high salinity as intracellular osmolytes (Mangum 1983), and that $\mathrm{Zn}$ is an essential component stabilising the quaternary structure of haemocyanin (Martin et al. 1977). The lack of such an effect in Palaemon elegans may be a species difference related to the salinity range inhabited, and/or a result of the masking of a low short-term increase in haemocyanin concentration in the prawns at $25 \% \mathrm{SW}$ by the marked individual variability in prawn haemocyanin concentrations (Taylor et al. 1985).

Alternatively the initial increase in body $\mathrm{Zn}$ concentrations in Palaemonetes varians in low salinities may result from an increased requirement for the $\mathrm{Zn}$-containing enzyme carbonic anhydrase. Henry \& Cameron (1982) and Henry (1984) showed that the concentration of the Zn-containing enzyme carbonic anhydrase increased in gills of the blue crab Callinectes sapidus acclimated to low environmental salinities, in response to the associated greater active uptake on ions. Body concentrations of $\mathrm{Zn}$ associated with carbonic anhydrase either do not rise significantly in Palaemon elegans at low salinities, or any such rise is accommo- dated by changes in the internal disposition of body $\mathrm{Zn}$. In addition, in strong osmoregulators like Palaemonetes spp., the rate of salt loss across the body surface appears to be reduced with short-term exposure to more dilute media (Mantel \& Farmer 1983). Whether the initial increase in body $\mathrm{Zn}$ concentration is related to such an ion-regulatory phenomenon remains to be shown.

Prior acclimation to either $50 \%$ or $25 \%$ SW did not affect the subsequent rate of $\mathrm{Zn}$ uptake by Paldemonetes varians in $25 \% \mathrm{SW}$. This result suggests that differences in $\mathrm{Zn}$ uptake between decapod species result from permanent intrinsic differences as opposed to temporary effects entrained by recent environmental history.

$\mathrm{Zn}$ was more toxic to Palaemonetes varians in $50 \%$ SW at $15^{\circ} \mathrm{C}$ than at $20^{\circ} \mathrm{C}$, and the threshold concentrations for $\mathrm{Zn}$ regulation breakdown also showed an inverse relation with temperature, as for Palaemon elegans (White \& Rainbow 1984a, Nugegoda \& Rainbow 1987). For both prawns therefore, reduced salinity and raised temperatures increase $\mathrm{Zn}$ bioavailability, enhancing $\mathrm{Zn}$ uptake and promoting the possible accumulation of lethal body $\mathrm{Zn}$ concentrations.

In summary therefore $\mathrm{Zn}$ uptake and regulation by decapods are affected by extrinsic physico-chemical factors such as changes in salinity and temperature, and by intrinsic features of the species themselves, related presumably to their adaptations to the physicochemical characteristics of their typical habitats.

Acknowledgements. This work was carried out while D. N. was in receipt of a Commonwealth Scholarship (Association of Commonwealth Universities) and P. S. R. was supported by NERC Grant GR3/5256. We are grateful to Mr M. Slater and Mr A. G. Scott for their advice.

\section{LITERATURE CITED}

Bryan, G. W (1964). Zinc regulation in the lobster Homarus vulgaris. I. Tissue zinc and copper concentrations. J. mar. biol. Ass. U.K. 44: 549-563

Bryan, G. W., Hummerstone, L. G. (1973). Adaptation of the polychaete Nereis diversicolor to manganese in estuarine sediments. J. mar biol. Ass. U.K. 53: 859-872

Bryant, V., Newbery, D. M., McLusky, D. S., Campbell, R. (1985). The effect of temperature and salinity on the toxicity of nickel and zinc to two estuarine invertebrates (Corophium volutator, Macoma balthica). Mar Ecol. Prog. Ser 24: 139-153

Engel, D. W., Fowler, B. A. (1.979). Factors influencing cadmium accumulation and its toxicity to marine organisms. Environ. Hith Perspect. 28: 81-88

Florence, T M. (1983). Evaluation of some physico-chemical techniques for the determination of the fraction of dissolved copper toxic to the marine diatom Nitzschia closterium. Analytica chim. Acta 151. 281-295

Henry, R. P. (1984). The role of carbonic anhydrase in blood iron and acid-base regulation. Am. Zool. 24: 241-251 
Henry, R. P., Cameron, J. N. (1982). Acid-base balance in the euryhaline blue crab Callinectes sapidus during acclimation from high to low salinity. J. exp. Biol. 101: 255-264

Jones, M. B. (1975). Synergistic effects of salinity, temperature and heavy metals on mortality and osmoregulation in marıne and estuarine isopods (Crustacea). Mar Bıl. 30: $13-20$

Mangum, C. P. (1983). Oxygen transport in the blood. In: Mantel, L. H. (ed.) The biology of Crustacea. Vol. 5. Internal anatomy and physiological regulation. Academic Press, New York, p. 373-429

Mantel, L. H., Farmer, L. L. (1983). Osmotic and ionic regulation. In: Mantel, L. H. (ed.) The biology of Crustacea Vol. 5. Internal anatomy and physiological regulation Academic Press, New York, p 54-161

Mantoura, R. F. C. Dickson, A., Riley, J. P. (1978). The complexation of metals with humic materials in natural waters. Estuar coast. mar Sci. 6: 387-408

Martin, J. L. M., Van Wormhoudt, A., Ceccaldi, H. J. (1977). Zinc-haemocyanin binding in the hemolymph of Carcinus maenas (Crustacea: Decapoda). Comp. Biochem. Physiol. 58A: $193-195$

McKenney, C. L., Neff, J. M. (1979). Individual effects and interactions of salinity, temperature and zinc on larval development of the grass shrimp Palaemonetes pugio. I. Survival and development duration through metamorphosis. Mar Biol. 52: 177-188

McLusky, D. S., Bryant, V., Campbell, R. (1986). The effects of temperature and salinity on the toxicity of heavy metals to marine and estuarine invertebrates. Oceanogr. mar. Biol A. Rev. 24: 481-520

Morris, S., Taylor, A. C. (1983). Diurnal and seasonal variation in physico-chemical conditions within intertidal rockpools. Estuar. coast. Shelf Sci. 17: 339-355

Nugegoda, D., Rainbow, P. S. (1987). The effect of temperature on zinc regulation by the decapod crustacean Palaemon elegans Rathke. Ophelia 27: 17-30

Nugegoda, D., Rainbow, P. S. (1988). Effect of a chelating agent (EDTA) on zinc uptake and regulation by Palaemon elegans (Crustacea: Decapoda). J. mar. biol. Ass. U.K. 68 : $25-40$

Panikkar, N. K. (1941). Osmoregulation in some palaemonid prawns. J. mar. biol. Ass. U.K. 25: 317-359

Parry, G. (1955). Urine production by the antennal glands of Palaemonetes varians (Leach). J. exp. Biol. 32: 408-422
Phillips, D. J. H. (1976). The common mussel Mytilus edulis as an indicator of pollution by zinc, cadmium, lead and copper I. Effects of environmental variables on uptake of metals. Mar Biol. 38: 59-69

Phillips, D. J. H. (1980). Quantitative aquatic biological indicators. Their use to monitor trace metal and organochlorine pollution. Applied Science Publishers, London

Rainbow, P. S. (1988). The significance of trace metal concentrations in decapods. In: Fincham, A. A., Rainbow, P. S. (eds.) Aspects of decapod crustacean biology. Clarendon Press, Oxford. Symp. Zool. Soc. Lond. 59: 291-313

Ramirez de Isla Hernandez, S., Taylor, A. C. (1985). The effects of temperature on osmotic and ionic regulation in the prawn, Palaemon elegans (Rathke). Ophelia 24: 1-15

Smaldon, G. (1979). British coastal shrimps and prawns. Synopses of the British Fauna (New Series). No. 15. Linnean Soc. Lond. Academic Press, London

Sokal, R. R., Rohlf, F. J. (1981). Biometry, 2nd edn. Freeman and Co., San Francisco

Sunda, W. G., Engel, D. W., Thuotte, R. M. (1978). Effects of chemical speciation on toxicity of cadmium to grass shrimp Palaemonetes pugio; importance of free cadmium ion. Environ. Sci. Technol. 12: 409-413

Taylor, A. C., Morris, S., Bridges, C. R. (1985). Modulation of haemocyanin oxygen affinity in the prawn, Palaemon elegans (Rathke) under environmental salinity stress. J. exp. mar biol. Ecol. 94: 167-180

White, S. L., Rainbow, P. S. (1982). Regulation and accumulation of copper, zinc and cadmium by the shrimp palaemon elegans. Mar Ecol. Prog. Ser 8: 95-101

White, S. L., Rainbow, P. S. (1984a). Regulation of zinc concentration by Palaemon elegans (Crustacea: Decapoda): zinc flux and effects of temperature, zinc concentration and moulting. Mar. Ecol. Prog. Ser. 16: 135-147

White, S. L., Rainbow, P. S. (1984b). Zinc flux in Palaemon elegans (Crustacea: Decapoda): moulting, individual variation and tissue distribution. Mar Ecol. Prog. Ser 19: 153-166

Wright, D. A. (1977). The effect of calcium and cadmium uptake by the shore crab Carcinus maenas. J. exp. Biol. 67 . $163-173$

Zamuda, C. D., Sunda, W. G. (1982). Bioavailability of dissolved copper to the American oyster Crassostrea virginica. I. Importance of chemical speciation. Mar. Biol. 66: $77-82$ 